\title{
Hanford Environmental Dose Reconstruction Project
}

Monthly Report

July 1991
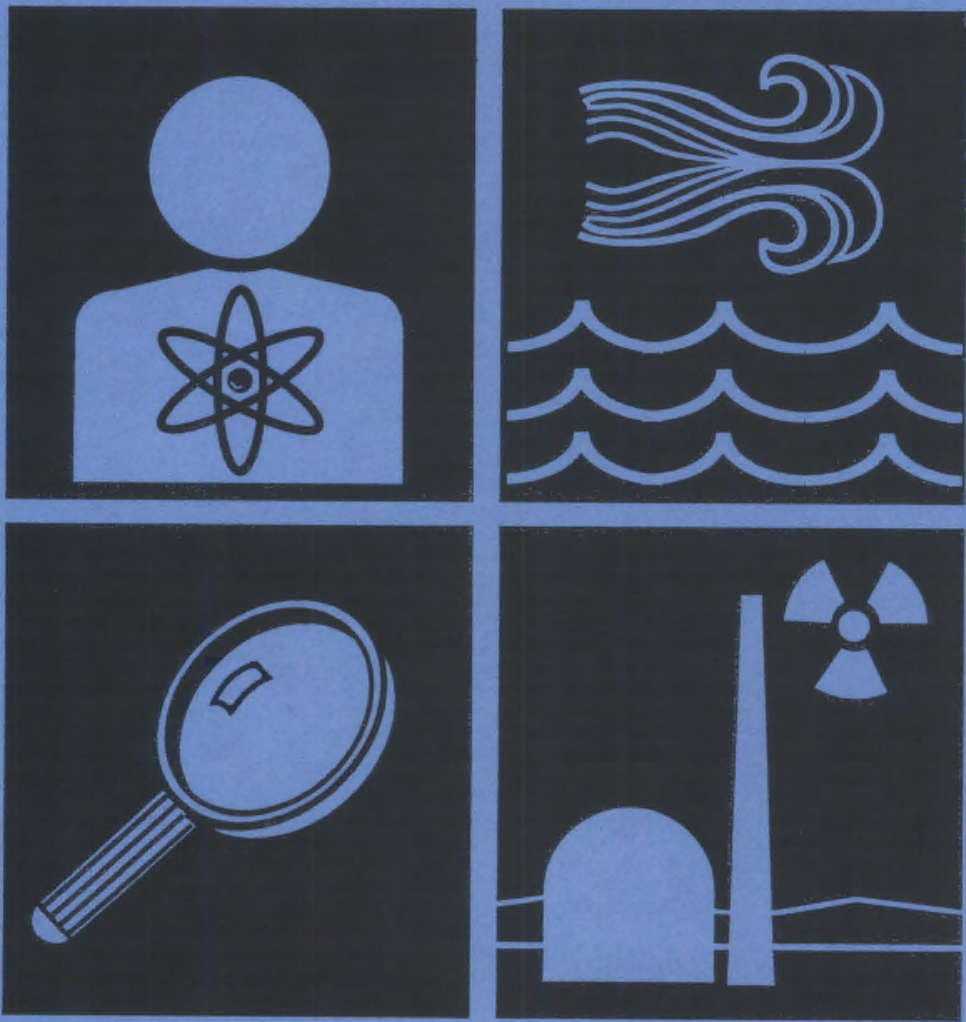

Prepared for the Technical Steering Panel

\% Battelle 


\section{DISCLAIMER}

This report was prepared under the direction of the HANFORD ENVIRONMENTAL DOSE RECONSTRUCTION PROJECT Technical Steering Panel by Battelle Memorial Institute's Pacific Northwest Laboratories operating the Pacific Northwest Laboratory for the U.S. Department of Energy (DOE). While funding for the work was provided by DOE, the work is not under DOE direction or control. The views and opinions of the authors expressed in this document do not necessarily reflect those of the United States Government or any agency thereof. Reference herein to any specific commercial product, process or service by trade name, trademark, manufacturer or otherwise does not necessarily constitute or imply its endorsement, recommendation or favoring by the U.S. Government or any agency thereof, nor by Battelle Memorial Institute.

Printed in the United States of America

Available to DOE and DOE contractors from the

Office of Scientific and Technical Information, P.O. Box 62, Oak Ridge, TN 37831 ; prices available from (615) 576-8401. FTS 626-8401.

Available to the public from the National Technical information Service, U.S. Department of Commerce, 5285 Port Royal Rd., Springfieid, VA 22161. 
PNL-6450-45-HEDR

UC-707

HANFORD ENVIRONMENTAL DOSE RECONSTRUCTION PROJECT

\section{Monthly Report}

July 1991

Prepared for the Technical Steering Panel

Pacific Northwest Laboratory

Richland, Washington 99352 

HANFORD ENVIRONMENTAL DOSE RECONSTRUCTION PROJECT

Compiled By:

S. M. Finch, Project Coordinator

Hanford Environmental Dose Reconstruction Project

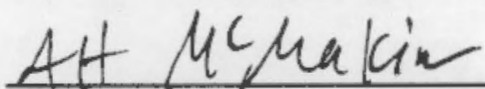

A. H. McMakin, Communication Specialist Hanford Environmental Dose Reconstruction Project

Approved By:

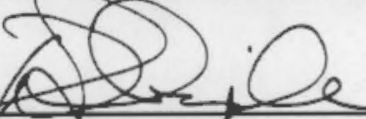

D. B. Shipler, Mrnager

Hanford Environmental Dose Reconstruction Project

Approved By:

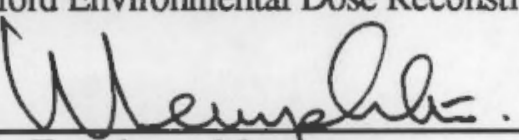

W. L. Templeton, Manager

NEPA Implementation and Enviroumental Documentation 



\section{Preface}

This monthly report summarizes the technical progress and project status for the Hanford Environmental Dose Reconstruction (HEDR) Project being conducted at the Pacific Northwest Laboratory (PNL) (a) under the direction of a Technical Steering Panel (TSP). The TSP is composed of experts in numerous technical fields related to this project and represents the interest of the public. The U.S. Department of Energy (DOE) funds the project.

Figure 1 shows the PNL organizational structure of the HEDR Project. Table 1 shows the status of PNL work to comply with directives issued by the TSP.

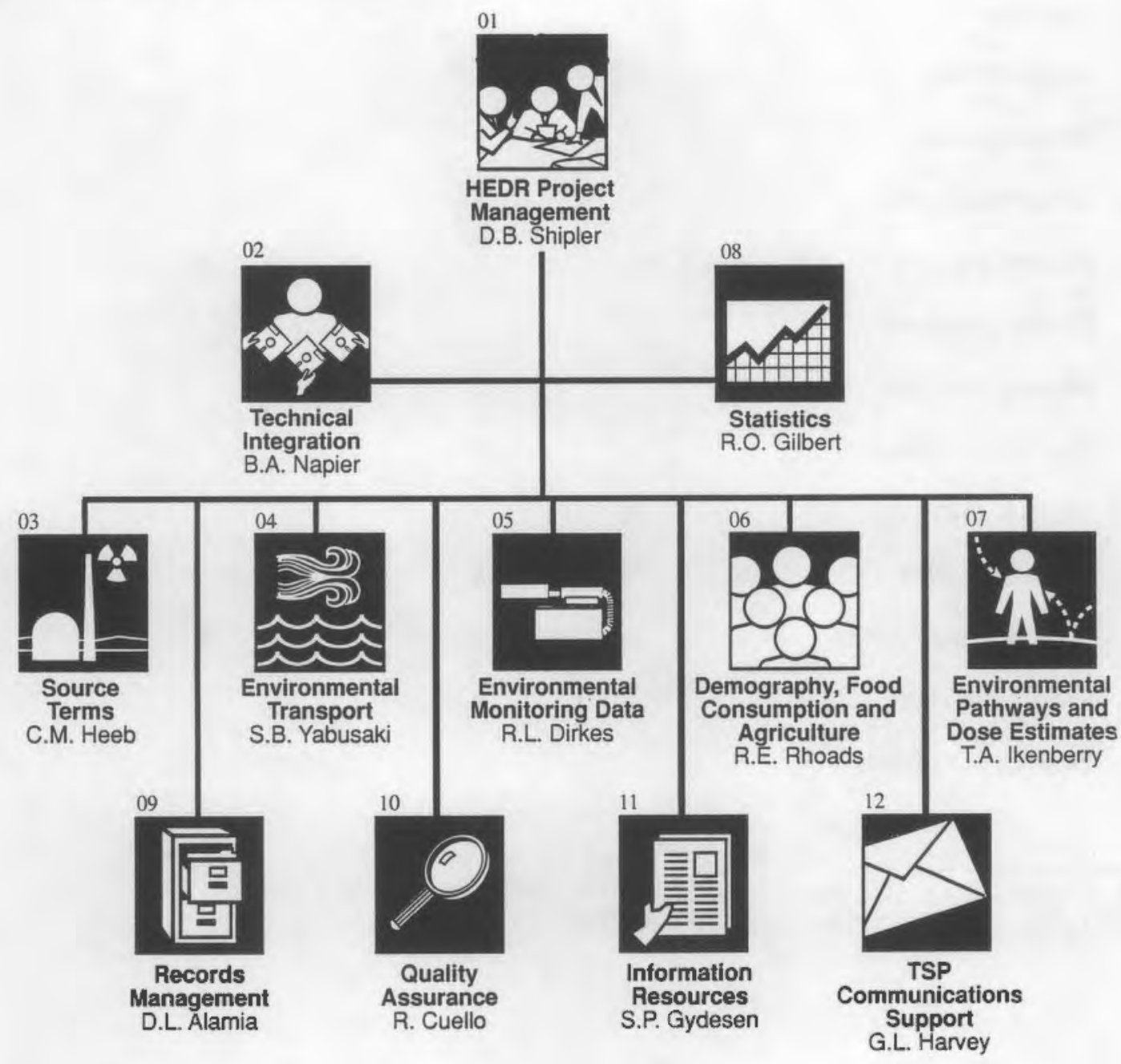

FIGURE 1. Organizational Structure of the Hanford Environmental Dose Reconstruction Project

(a) Battelle Memorial Institute operates the Pacific Northwest Laboratory. 
TABLE 1. Status of Directives(a)

\section{Complete Ongoing Phase I FY 1991}

88-1

(a) Proposals

(b) Source Terms

88-2 Vegetation

88-3 Status Reports

884 Ground Water

$88-5$

$88-6$

89-1 Indian Tribes

89-2 Bioassay Data

89-3 Document Handling

89-4 Reactor Purging

89-5 Phased Approach

89-6 Meeting Materials

89-7 Tech Communication

89-8 Phase II Planning

89-9 Project QA Plan

89-10 Contracts with Tribes

90-1 Project Direction

90-2 Dose Cut-Off Limit
$\mathbf{X}$

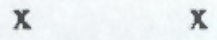

x $\quad$ X

$\mathbf{X}$

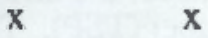

X

$\mathbf{x}$

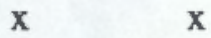

$\mathbf{X}$

$\mathbf{x}$

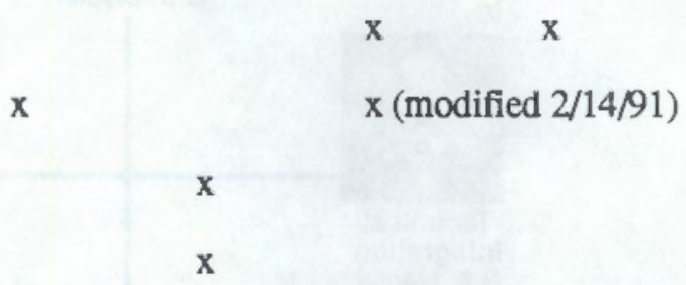

X

$\mathbf{X}$

$\mathrm{x}$ (revised)

$\mathbf{x}$

$\mathrm{x}$

$\mathbf{x}$

$x$

$x$

$x$




\section{Executive Summary}

The objective of the Hanford Environmental Dose Reconstruction Project is to estimate the radiation doses that individuals and populations could have received from nuclear operations at Hanford since 1944. The project is being managed and conducted by the Pacific Northwest Laboratory (PNL) under the direction of an independent Technical Steering Panel (TSP).

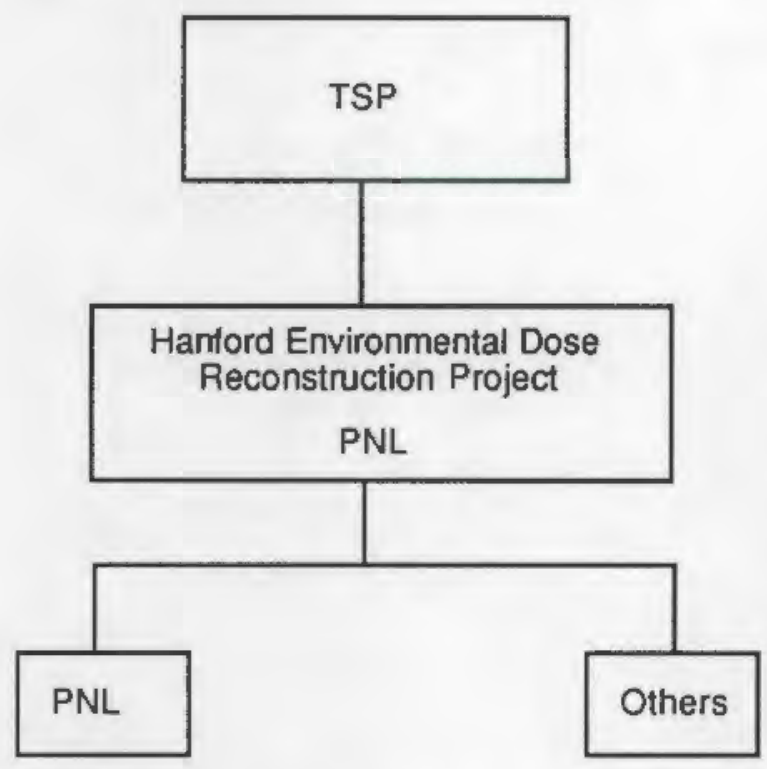

The TSP consists of experts in environmental pathways, epidemiology, surface-water transport, ground-water transport, statistics, demography, agriculture, meteorology, nuclear engineering, radiation dosimetry, and cultural anthropology. Included are appointed technical members representing the states of Oregon and Washington, cultural and technical experts nominated by the regional Native American tribes, and an individual representing the public.

The project is divided into the following technical tasks. These tasks correspond to the path radionuclides followed, from release to impact on humans (dose estimates):

- Source Terms

- Environmental Transport

- Environmental Monitoring Data

- Demographics, Agriculture, Food Habits

- Environmental Pathways and Dose Estimates.

The Source Terms Task develops estimates of radioactive emissions from Hanford facilities since
1944. These estimates are based on historical measurements and production information.

The Environmental Transport Task reconstructs the movement of radioactive materials from the areas of release to populations. Movement via the atmosphere, surface water (Columbia River), and ground water is studied.

The Environmental Monitoring Data Task assembles, evaluates, and reports historical environmental monitoring data. A major effort of this task is to separate Hanford as a source of radionuclide concentrations in the environment from concentrations caused by natural sources and nuclear testing fallout.

The Demographics, Agriculture, Food Habits Task develops the data needed to identify the populations that could have been affected by the releases. Population and demographic information are developed for the general population within the study area. This information will also be developed for several special population groups, including Native American tribes in the study area, Army personnel who were stationed at Hanford, Hanford construction workers, and migrant farm workers.

In addition to population and demographic data, the food and water sources and consumption pattems for populations are estimated because they provide a primary pathway for the intake of radionuclides. Historical dairy farming practices and milk distribution systems are studied because milk is a significant pathway for iodine- 131 to enter the human body. Cows could have eaten vegetation contaminated with this radionuclide.

Lifestyle and food habit information will also be developed for individuals included in the Hanford Thyroid Disease Study as a basis for dose estimates and for other interested individuals.

The Environmental Pathways and Dose Estimates Task uses the information produced by the other tasks to estimate the radiation doses populations could have received from Hanford radiation.

Project reports and Hanford-originated references used in the reports are made available to the public in a public reading room. Project progress is documented in this monthly report, which is available to the public. 



\section{Project Summary}

\section{Progress}

Figure A.1 in Appendix A shows the status of project milestone activities. The following is a summary of activities conducted by HEDR staff in July 1991:

- prepared draft task plans for FY 1992, 1993, 1994, and 1995 and submitted them to the TSP for review

- met with TSP members and with O. Hoffman before the July TSP meeting in preparation for the meeting. The meeting with Hoffman was part of his independent evaluation of the HEDR environmental transport and dose estimating models.

- received approval from the TSP to adjust FY 1991 budget to complete approved work

- provided a briefing on Hanford document search, retrieval and declassification to DOE Field Office, Richland (RL) manager

J. Wagoner, including a tour of the 3760 and 712 Buildings where Hanford documents are stored

- provided technical and scheduling comments to J. Till on his proposed work plan for the remainder of the project

- met with K. Kopecky (TSP) and other Hanford Thyroid Disease Study staff to discuss the survey form and data and model input issues

- prepared for an internal audit to be conducted in August

- received final TSP approval on, and published, the following reports:

- Air Pathway Report (Milestone 0102A)

- Columbia River Pathway Report (0102A)

- Selection of Dominant Radionuclides for Phase I of the HEDR Project (Milestone 0201A)

- Computational Model Design Specification for Phase I of the HEDR Project (Milestone 0201B)
- submitted the report titled Dose Estimate Variability Caused by Air Model Uncertainties (Milestone 0402E) to the TSP for review

- completed groundwater analyses of the Hanford Site, riparian wells, and watersheds, and continued writing the report documenting this work

- reviewed 15 Oregon State University reports from the 1960 s and 70 s to get data on river contamination

- provided a copy of the environmental monitoring document database and source term database to the RL Public Reading Room

- placed a work order with the Kalispel Tribe to gather supplementary information to be used in dose estimation

- developed and facilitated for tribal project staff members a training session on data collection design

- finalized air pathway dose code design and began coding the environmental accumulation submodel

- received a letter from General Electric expressing their willingness to cooperate with us in identifying Hanford-originated documents describing historic operations or environmental issues

- declassified 87 Hanford Site-originated documents, four of which are of potential interest/ use to the project and the remainder of which are from the TSP single-request listing

- provided the RL Public Reading Room with 137 documents of potential interest/use in the project

- signed a contract with RXL Productions, Inc. to produce the TSP videotape

- provided HEDR Project information to citizens from San Diego, Richland, and Philadelphia and referred them to the toll-free number 


\section{Problems or Changes and Action Taken}

There is a potential for slippage of work scheduled for the remainder of FY 1991 because of time spent by HEDR staff responding to TSP requests to prepare additional planning information for the August TSP budget/planning meeting.

\section{Planned Work for the Next Three Months}

- submit FY 1992 - 1993 task plans to the CDC in response to their request for proposal for dose reconstruction work expected in early September

- develop task plans for FY 1993 based on TSP direction at the August budget/ planning meeting

- submit the following milestones to the TSP:

- Project Management Plan

- Phase I final reports

- Draft code design specifications

- Documented Phase I iodine-131 releases

- Documented significant airborne and waterbome radionuclides, 1944 - 57

- Wind field modeling white paper

- Phase I reports on environmental monitoring data, population, food, and milk distribution estimate
- Vegetation data report

- Letter report on milk outside Phase I

- Iodine-131 conversion factor report

- Intemal audit report

- complete atmospheric release model

- complete restructure of atmospheric code and working version of restructured environmental/dose code

- investigate University of Washington surface water documents to obtain river monitoring data

- document tribal training session, review tribal interview guides, and review preliminary tribal food consumption data

- present a summary of communications assessment survey results to the TSP Communications Subcommittee

\section{Budget Status}

Figure 2 shows the budget status of the HEDR Project. Table A.1 in Appendix A shows FY 1991 costs and budget by task and subtasks. Figure A.2 shows TSP budget status.

\section{Capital Status}

$\$ 29 \mathrm{~K}$ of capital funding was approved for the procurement of a SPARC/RISC computer system. The $\$ 29 \mathrm{~K}$ plus $\$ 106 \mathrm{~K}$ of carryover gave the project a total of $\$ 135 \mathrm{~K}$ capital funding for FY 1991. 


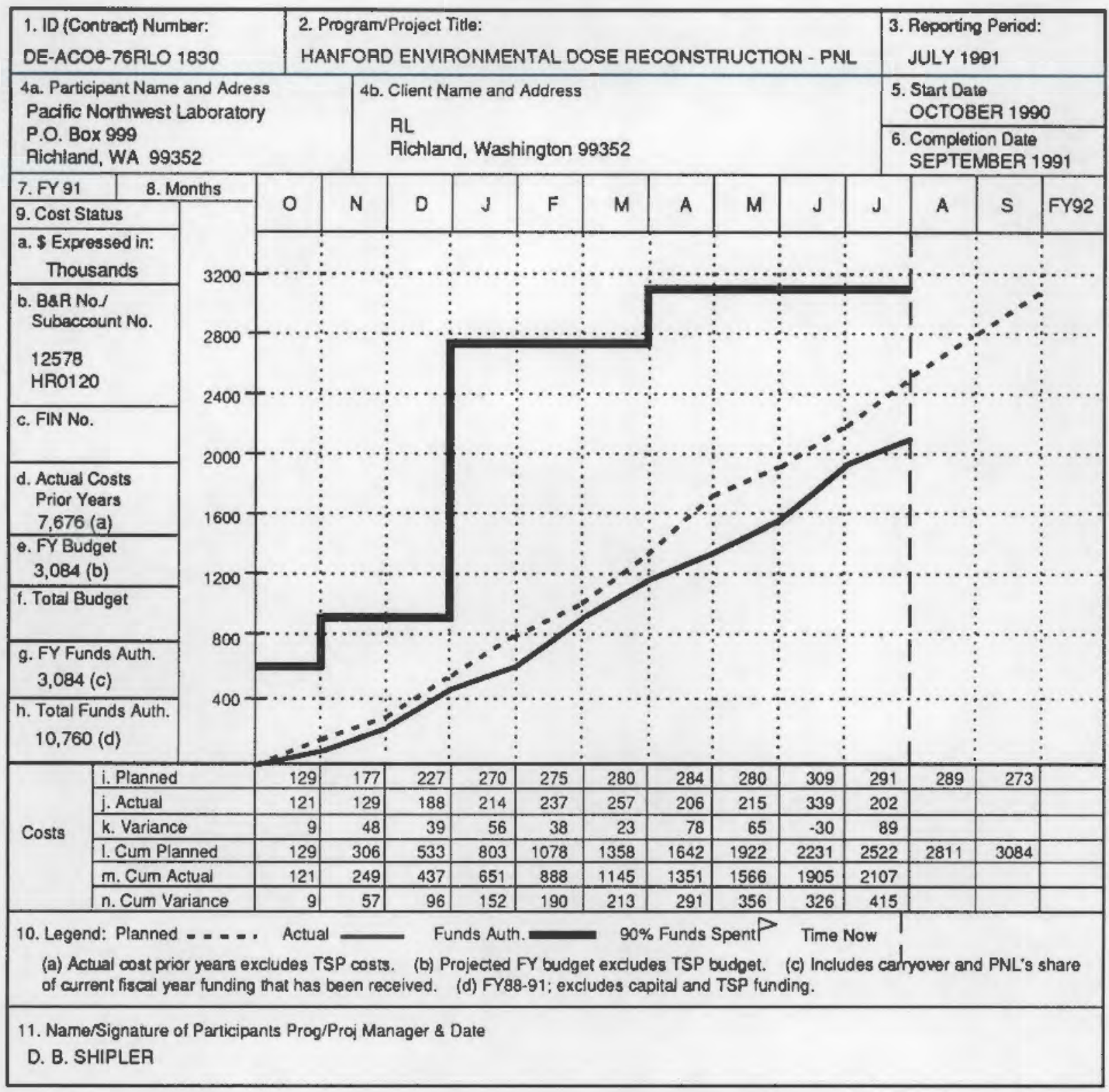

FIGURE 2. HEDR Project Budget Status - Pacific Northwest Laboratory 



\section{Contents}

Preface. ............................ v

Executive Summary. ............................ vii

Project Summary $\ldots \ldots \ldots \ldots \ldots \ldots \ldots \ldots \ldots \ldots \ldots \ldots \ldots \ldots$ ix

Task 01 - PNL Project Management. . . . . . . . . . . . . . . . . . 1.1

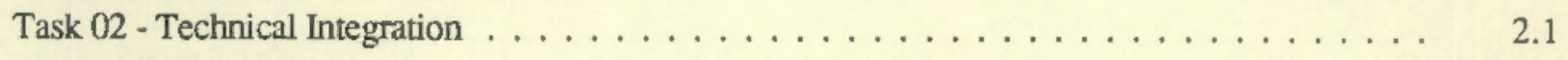

Task 03 -Source Terms . . . . . . . . . . . . . . . . . . . . . 3.1

Task 04 - Environmental Transport . . . . . . . . . . . . . . . . . 4.1

Task 05 - Environmental Monitoring Data $\ldots \ldots \ldots \ldots \ldots \ldots \ldots \ldots$

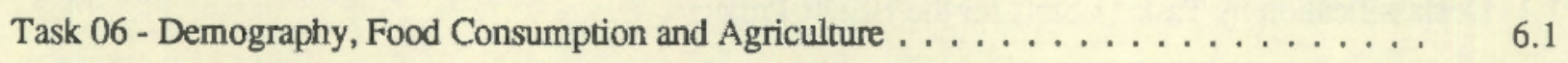

Task 07 - Environmental Pathways and Dose Estimates . . . . . . . . . . . . . 7.1

Task 08 - Statistics . . . . . . . . . . . . . . . . . . . . 8.1

Task 09 - Records Management . . . . . . . . . . . . . . . . . . . 9.1

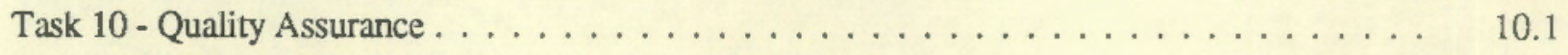

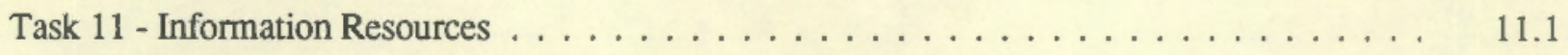

Task 12 - TSP Communications Support . . . . . . . . . . . . . . . 12.1

Appendix A - Milestones, Schedule and Costs . . . . . . . . . . . . . . A.1

Appendix B - Hanford Site-Originated Documents of Potential Interest/Use to the HEDR
Project - Placed in the RL Public Reading Room During July 1991 . . . . . . . . B.1

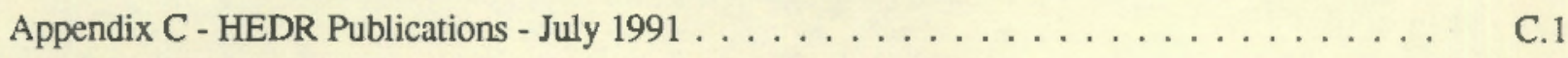

Appendix D - HEDR Presentation Handouts to the TSP - July $1991 \ldots \ldots \ldots \ldots$. . . . . . . .

Appendix E - HEDR-Related Publications and Presentations - July 1991 . . . . . . . . . . . E.1

Appendix $\mathrm{F}$ - Communications $\log$ - July $1991 \ldots \ldots \ldots \ldots \ldots$. . . . . . . . . F 


\section{Figures}

1 Organizational Structure of the Hanford Environmental Dose Reconstruction Project . . . . v

2 HEDR Project Budget Status - Pacific Northwest Laboratory . . . . . . . . . . . . . . xi

A.1 HEDR Project Milestones . . . . . . . . . . . . . . . . . . A.1

A.2 Technical Steering Panel Budget Status $\ldots \ldots \ldots \ldots \ldots \ldots \ldots \ldots$

\section{Tables}

1 Status of Directives. ......................... vi

11.1 Declassification by Task 11 Staff for the HEDR Project $\ldots \ldots \ldots \ldots \ldots \ldots \ldots$

A.1 Cost Summary . . . . . . . . . . . . . . . . . A.4 


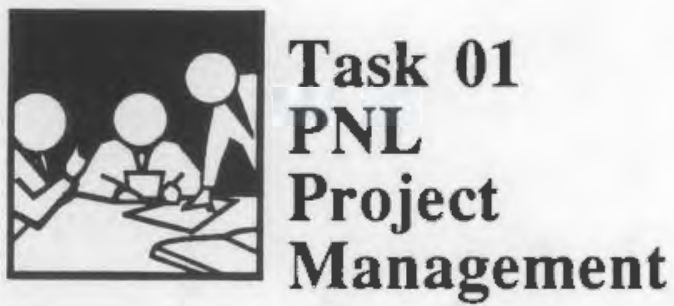

\section{Objective}

The objective of the PNL Project Management Task is to provide project planning, control, and management of PNL dose reconstruction work in accordance with TSP direction.

\section{Progress}

Milestone 0101B - FY 1992, 1993, 1994, and 1995 Task Plans, due July 1991 and completed

- prepared draft task plans for all years and submitted to the TSP for review

\section{Milestone 0101C - Project Management} Plan, due September 1991

- met with staff to discuss the annotated outline

\section{Milestone 0102A - Final Phase I Reports}

(Summary, Air, River), due May 1991 and rescheduled to August 1991

- issued two of the three reports as final versions: Air Pathway Report and Columbia River Pathway Report. TSP comments were addressed, and the reports were approved for final publication by J. Till. The Summary Report will be sent to the TSP early next month for final approval.

\section{Other Activities}

- provided B. Shleien, TSP, with a set of requested visual materials

\section{Major Problem Areas or Changes and Action Taken}

There is a potential for FY 1991 work slippage due to additional TSP-requested planning for FY 1992 1993. No additional funds are needed to complete the FY 1991 work; however, some work may need to be completed in early FY 1992.

\section{Variance}

The cumulative cost underrun was caused by an unanticipated cost credit from Battelle's general and administrative overheads. In addition, the Phase I Summary Report is not yet finalized.

\section{Planned Work for the Next Three Months}

- finalize Phase I Summary Report

- respond to TSP direction on task plans and budget for FY 1992, 1993, and 1994, and prepare them for response to a request for proposal from the CDC

- prepare a time-phased network of approved activities for the remainder of the project

- prepare a project management plan 



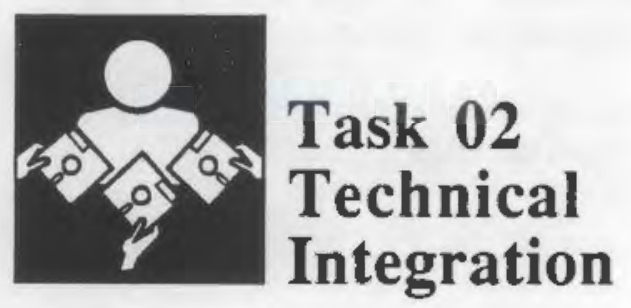

\section{Objective}

The objective of the Technical Integration Task is to provide technical overview of the project to ensure that appropriate technical activities are planned, that appropriate information is generated, and that technical task work is integrated effectively for performing the final dose calculations.

\section{Progress}

Milestone 0201A - Dominant Radionuclides Final Report, due April 1991, rescheduled to June 1991 and completed

- sent final version to TSP Chair for approval

Milestone 0201B - Model Specification Final Report, due April 1991, rescheduled to June 1991 and completed

- sent final version to TSP Chair for approval

Milestone 0202A - Draft Code Design Specifications, due April 1991 and rescheduled to September 1991

- received comments from authors and computer implementors; preparing second draft for intemal clearance

- received input from Task 08 (Statistics) staff on use of Latin Hypercube Sampling in the dose code to determine dose uncertainties

Milestone 0202C - Model Correlations Analysis Report, due February 1991 and completed

- continued to revise the report to respond to TSP comments

\section{Other Activities}

- met with TSP consultant F. O. Hoffman before the July TSP meeting to review the HEDR dose model

- participated in Native American Working Group meeting in Spokane, Washington

- participated in meeting with staff of Hanford Thyroid Disease Study (HTDS) in Richland, Washington

- continued developing decision analysis techniques for project application

\section{Major Problem Areas or Changes and Action Taken}

None.

\section{Variance}

No significant cumulative variance.

\section{Planned Work for the Next Three Months}

- complete revision of Milestone 0202C, Model Correlations Analysis Report 
- prepare code design specifications for the project computational model, completing Milestone 0202A

- attend Native American Working Group meetings

- continue coordinating efforts with HTDS personnel

- submit Hanford scenario to the International Atomic Energy Agency Coordinated Research Program on Validation of Model Predictions (VAMP) to validate portions of the HEDR model and obtain independent estimates of certain doses, completing Milestone 0203B
- conduct computer study to check accuracy of random number generators available on the selected computer system

- begin to develop the plan for conducting sensitivity and uncertainty analyses of the dose code $\square$ 


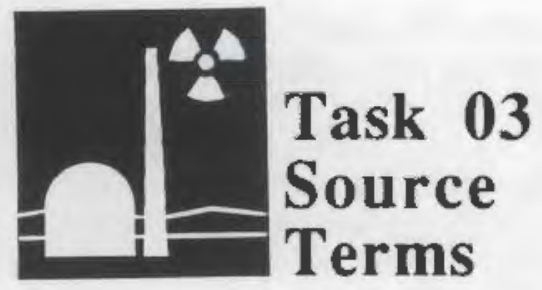

\section{Objective}

Source terms are the amount and type of radioactive materials released to the environment. Members of the Source Terms Task develop estimates of radioactive emissions since 1944 from Hanford facilities based on historical measurements and production information. Source term estimates are used by Environmental Transport Task members to reconstruct the concentrations of radionuclides in the environment.

Uncertainty in calculated and measured data can result from many factors. Uncertainties in measured emissions may result from early measurement techniques. For calculated emissions, uncertainties may result from the differences in published variables that are used to perform calculations. By comparing the uncertainty in the available data, Source Term Task staff determine the most accurate method for developing source terms. For time periods where measured values do not exist, source terms are calculated from available information. The proposed methods and results of this task are reviewed, evaluated, and approved by the TSP.

\section{Progress}

\section{Milestone 0302A - Documented Phase I Iodine-131 Releases, due May 1991 and rescheduled to September 1991}

- continued, and nearly completed, calculating the 1944-1947 iodine-131 releases. The key references were identified, and cross comparisons between two independent references were made that allowed defensible reconstruction.

\section{Milestone 0305A - Iodine-131 Release Model Report, due FY 1992}

- began developing the release model by writing software control procedures and initial specifications

\section{Other Activities}

- presented the status of the Source Term Task at the Source Tem Subcommittee meeting at the July TSP meeting in Pasco

\section{Major Problem Areas or Changes and Action Taken}

The dissolver operation reconstruction in Subtask 0302, Iodine-131 Closure, was not completed in July. The milestone for the completion of this subtask, originally scheduled for May 1991 and rescheduled to August, must now be moved to the end of September. During the July Source Term Subeommittee meeting, the TSP agreed to delay the milestone document until results from the release model could be used to better define the uncertainties. This proposal was accepted. The 
key interaction of Subtask 0305 (Release Model) with other tasks is the delivery of input files for the dose model in mid-September. Iodine-131 closure work will continue because the basic data will be in hand well before the Milestone 0302A report is completed at the end of September.

The same personnel involved in the iodine-131 closure subtask are also involved in Subtasks 0303 (Airborne Isotopes Other Than Iodine-131) and 0304 (Waterbome Isotopes 1944-1957). Therefore, the July milestones for these subtasks must be moved to the end of September.

\section{Variance}

The cumulative cost underrun was caused by delaying the start of the detailed work on Subtask 0305 (Release Model). The delay was made to allow work on the iodine-131 estimates in Subtask 0302.

\section{Planned Work for the Next Three Months}

- continue work on Subtask 0302 (Iodine Closure); provide preliminary results by mid-August

- complete documentation for Subtask 0303 (Significant Airbome Releases) and Subtask 0304 (Significant Waterborne Releases) by the end of FY 1991

- complete Subtask 0305 (Release Model) by the end of FY 1991. Preliminary results will be available as input to the atmospheric model, but documentation, verification, and validation will be completed in subsequent years as originally planned. 


\section{Objective}

Members of the Environmental Transport Task reconstruct the movement of radioactive materials (the source term information) from the areas of release to the environment. Radionuclide movement via the atmosphere, Columbia River, and groundwater are studied.

To track releases to the atmosphere from Hanford Site operations, meteorological data are needed, including wind speed, wind direction, and other data that affect the dispersion of the releases. Mathematical models are applied to these meteorological data and the source term data to calculate concentrations of radionuclides in the air and on the ground. The TSP reviews, evaluates, and provides direction concerning the proposed models.

Reconstruction of the transport of radionuclides in the Columbia River is based primarily on historical studies of the Columbia River and its tributaries. Computer models are used to reconstruct radionuclide concentrations in the river for time periods when previously published data are limited or unavailable.

The movement of radionuclides in the groundwater is reconstructed initially by using groundwater monitoring data to estimate the contribution to the Columbia River exposure pathway. Modeling will be used where previously published data are lacking.

\section{Progress}

Milestone 0402A - Wind Field Modeling White Paper, due April 1991 and rescheduled to September 1991

- continued work on wind field models; presented results of work to date at the Juily TSP meeting

\section{Milestone 0402B - MESOILT2 Ver- sion 2.0 Report, due FY 1992}

- continued to revise and test version 2.0 of the MESOILT2 code. Worked on partitioning iodine between species for use in computing deposition. Began documenting results of the March meeting of the atmospheric model working group
Milestone 0402C - Report on Air Model Sensitivity/Uncertainty, due FY 1992

- began incorporating uncertainty in the distribution of iodine among various species in the atmospheric model. This uncertainty affects deposition and, consequently, the dose calculations.

\section{Milestone 0402D - Meteorological Data} Report, due FY 1992

- continued entry of meteorological data for 1944-1947 
Milestone 0402E - Report on Air Model Variability, due April 1991, rescheduled to July 1991, and completed

- provided milestone report to the TSP for review and comment

\section{Milestone 0403A - Groundwater Report, due FY 1992}

- completed groundwater analyses of the Hanford Site, riparian wells, and watersheds, and continued writing the section on offsite migration. Peer review and final editing of report chapter describing analysis will be conducted during FY 1992.

- reviewed Hanford monitoring documents for information on radionuclides in the groundwater. The review effort during July focused on monitoring documents from the 1960 s and 1970s. Met with staff from Task 11 (Information Resources) to ensure that key Hanford documents have been identified and reviewed.

- reviewed documents reporting results of an investigation into uranium contamination on the Franklin County side of the Columbia River to the east of the 300 Area

\section{Milestone 0404A - Columbia River Data,} 1944-1989, due FY 1992

- reviewed 15 Oregon State University Department of Oceanography reports from the $1960 \mathrm{~s}$ and early 1970 s. The data are primarily radionuclide concentrations in marine biota, mostly zinc-65. A few articles contain radionuclide concentrations in Columbia River sediments, with the emphasis on the estuary.

\section{Other Activities}

- presented progress on all subtasks to the Environmental Transport Subcommittee at the July TSP meeting

\section{Major Problem Areas or Changes and Action Taken}

To keep the surface-water transport subtask on schedule, an additional staff member is working on the data and literature review.

\section{Variance}

The cumulative cost underrun continues to be reduced. Approximately one person-month of effort for an indefinite-quantity contract was incorrectly charged to another project. A correction will be made to move the costs to Task 04 of the HEDR Project.

\section{Planned Work for the Next Three Months}

- continue evaluation of wind field interpolation methods

- restructure atmospheric code to be consistent with the overall dose assessment code

- continue work on databases for use with the revised atmospheric model

- continue reviewing and summarizing Hanford Site groundwater documents for the chapter on offsite migration

- continue the literature and database review for the surface water pathway, with emphasis shifting to the University of Washington Laboratory of Radiation Biology studies 


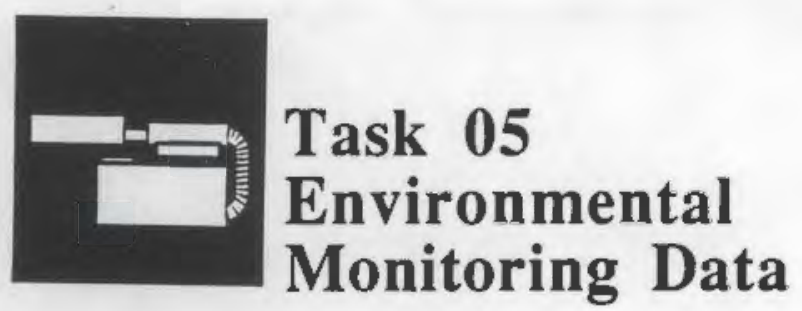

\section{Objective}

Members of the Environmental Monitoring Data Task assemble, evaluate, and summarize key historical measurements of the concentrations of radionuclides in the environment around the Hanford Site. Radionuclide concentrations have been measured at various times in air, drinking water, foods, fish, the Columbia River, soil, and in other materials. These measurements are evaluated to estimate their accuracies and then used by Environmental Pathways and Dose Estimates Task staff to estimate radiation doses and by Environmental Transport Task staff to calibrate computer models.

\section{Progress}

Milestone 0501A - Environmental Monitoring Data Final Report, due April 1991 and rescheduled to September 1991

- continued modification of the report to address TSP comments

\section{Milestone 0502A - Vegetation Data} Report, due September 1991

- continued to enter raw vegetation monitoring data available for 1948-1951. Continued to enter offsite vegetation monitoring data from 1951 into the database and began entering 1950 data. Draft biases, uncertainty, and conversion factor sections of the report have been prepared.

\section{Monitoring Document Search and} Inventory (Subtask 0503)

- continued cross-comparisons among the Environmental Monitoring Document Database (EMDD) list and the HEDR Information Resources Tracking System title entries
- provided a copy of the EMDD to the DOE Field Office, Richland (RL) Public Reading Room

Surface Water Data (Subtask 0404)

- conducted technical activities in support of Subtask 0404, Surface Water Transport (reported under Task 04)

\section{Major Problem Areas or Changes and Action Taken}

Milestone 0501A, Environmental Monitoring Data Final Report, was moved from August to September 1991. Staff required for the completion of this milestone have been unable to complete the report due to the need for revisions to the FY-92/93/94 task plans in preparation for the unexpected August TSP budget/fiscal meeting as well as commitments outside of HEDR. Time needed to complete the report will be available in August.

\section{Variance}

The cumulative underrun continues to be reduced. Staff will be verifying information up through the end for the fiscal year and expect to use remaining funds. 
Planned Work for the Next Three Months

- finalize Milestone 0501A, Environmental Monitoring Data Final Report

- collect and inventory additional Columbia River monitoring data
- continue to collect and inventory additional vegetation data and begin preparation of vegetation monitoring data report $\square$ 


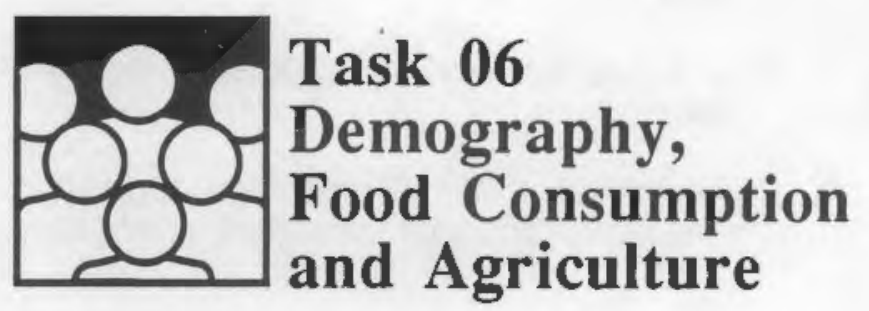

\section{Objective}

Task members develop the demographic, food consumption, and food production information needed to estimate doses. Demographic information for populations that may have been exposed to radionuclides during the time period of interest is developed for the general population and for several special population groups that are not adequately represented by the U.S. Census. These groups include Native American tribes, army personnel stationed at Hanford, some Hanford construction workers, and migrant workers.

Sources and quantities of food and water consumed by these populations must be estimated, because food and water provide pathways for the intake of radionuclides. In particular, milk produced from cows represents a significant food pathway for iodine-131 if the cows ate vegetation contaminated with radionuclides. Dairy farming practices and milk distribution systems are studied to identify the populations that may have consumed potentially contaminated milk.

Methods to collect data and to estimate population densities and food consumption are reviewed and approved by the TSP.

\section{Progress}

\section{Preliminary Native American Data} (Subtask 0602)

- placed a work order with the Kalispel Tribe to gather supplementary information

- met with the Native American Working Group to review a draft policy for collection and management of tribal data. Before being sent to the TSP for formal approval, this policy will be revised based on comments offered at the meeting.

- organized and facilitated for tribal project staff members a training session on data collection design. The training session was held in Spokane on July 29-30 and attended by representatives of all eight tribal subcontractors, in addition to representatives from the Indian Health Service, the HTDS, and the TSP.

\section{Major Problem Areas or Changes and Action Taken}

None.

\section{Variance}

The cumulative cost underrun was caused by the delay in tribal work. The Native American Working Group has completed development of a process for collecting the data. Work orders are now being placed for data collection activities. Also, efforts are under way to place a contract with Washington State University for milk model activities. 
Planned Work for the Next Three Months

- document tribal training session and associated action items

- review tribal interview guides

- identify common data compilation protocols
- review preliminary tribal food consumption data

- complete milk model verification for Phase I area

- complete general milk production, distribution, and consumption, for counties of interest for the HTDS $\square$ 


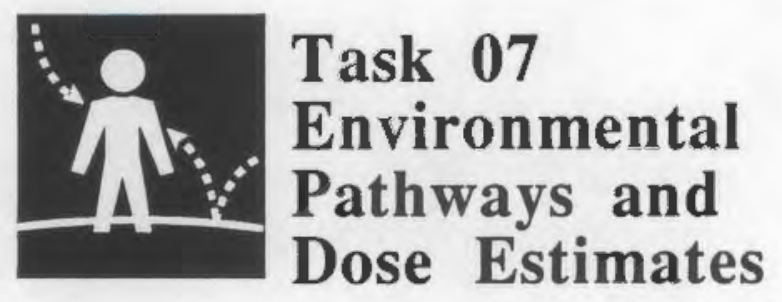

\section{Objective}

Task members use calculated and measured concentrations of radionuclides provided by members of the Environmental Transport Task and the Environmental Monitoring Data Task to calculate doses to populations, typical individuals, and specific individuals. These calculations include doses via direct transfer of radionuclides from concentrations in air and water to people (such as via breathing, drinking, and immersion). The calculations also include doses from radionuclide concentrations in air and water transferred through environmental pathways, such as soil, plants, animals, and fish, to people. All significant decisions on exposure models and input parameters are presented to the TSP for review, evaluation, and approval.

\section{Progress}

Code Restructure and Analysis (0702)

- presented information to the TSP on the status of the environmental pathways and dose model/code

- met with HTDS personnel from the Fred Hutchinson Cancer Research Center (FHCRC) to discuss the survey form and other data and model input issues

Milestone 0702A - Air Pathway Dose Code Documentation, due FY 1992

- finalized code design and began coding the environmental accumulation submodel

- continued working with Tasks 02 (Technical Integration) and 08 (Statistics) to evaluate hardware and software requirements for the restructured air pathway model/code
Milestone 0703A - Model Parameters

Report, due FY 1992

- continued literature review and documentation of radionuclide transfer factors

\section{Major Problem Areas or Changes} and Action Taken

None.

\section{Variance}

No significant cumulative variance.

\section{Planned Work for the Next Three Months}

- complete initial working version of restructured environmental/dose code (Milestone 0702A) 
- transfer initial environmental/dose code to SUN 4 computer system

- resume work on literature search and documentation of radionuclide transfer factors (Milestone 0703A) in October
- support Task 02 in completing the design specification document for the restructured air pathway code (Milestone 0202A) 


\section{Objective}

Task members provide statistical support to members of technical tasks and develop and apply sensitivity and uncertainty analyses. Sensitivity analyses will be used to identify parameters with the greatest influence on dose estimates. Using sensitivity analyses results, project staff can focus resources where the benefit in terms of accurate dose estimates is greatest. Uncertainty analyses enable task leaders to determine the extent to which the accuracy and precision of the dose estimates are influenced by accuracy and precision in the input parameters.

\section{Progress}

Milestone 0802A - Iodine-131 Conversion Factor Report, due September 1991

- continued report planning discussions with E. Mart (consultant), R. Dirkes (Task 05 leader), and B. Hanf. The report will estimate the sensitivity and uncertainty of factors used to convert historic (1945-1946) gross beta count-per-minute measurements on native vegetation (mostly sagebrush) to concentrations per unit weight of iodine-131.

- continued to develop methodology for conducting and interpreting the uncertainty/sensitivity analyses

- began software quality control documentation and required code development for the uncertainty analyses

- reviewed draft chapters in the companion paper being prepared by $\mathrm{E}$. Mart that will discuss the conversion factors in detail

\section{Other Activities}

- conducted activities to support Task 02 (Technical Integration) and Milestones $0402 \mathrm{C}$ and 0402E of Task 04 (Environmental Transport), as reported under Tasks 02 and 04

\section{Major Problem Areas or Changes and Action Taken}

None.

\section{Variance}

No significant cumulative variance.

\section{Planned Work for the Next Three Months}

- complete Milestone 0802A, lodine-131 Conversion Factor Report

- assist Task 03 (Source Terms) in incorporating uncertainty into source term model outputs

- continue to work with Task 02 (Technical Integration) and Task 04 (Environmental Transport) in support of Milestones 0202C, $0402 \mathrm{C}$, and 0402E 



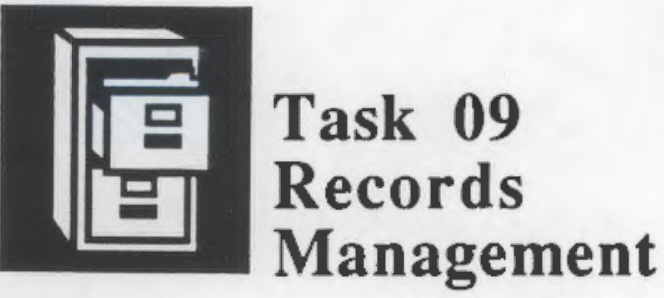

\section{Objective}

Members of the Records Management Task provide storage and control of completed project records, maintain an automated inventory of all project documentation, and provide a reference service to project staff and the TSP.

\section{Progress}

- presented a training session on records management requirements to project staff in preparation for upcoming internal audit

- met with several task and subtask leaders to provide information on records management requirements in preparation for the audit

- received project records from the HEDR Project Office (211 records/ $/ 7334$ pages)

- verified, processed, and stored project records (129 records/5844 pages)

- transferred four packages of records to the RL Public Reading Room (14 records/ 3569 pages)
Major Problem Areas or Changes and Action Taken

None.

\section{Variance}

No significant cumulative variance.

\section{Planned Work for the Next Three Months}

- continue processing incoming project records

- continue transferring processed project records to the RL Public Reading Room 



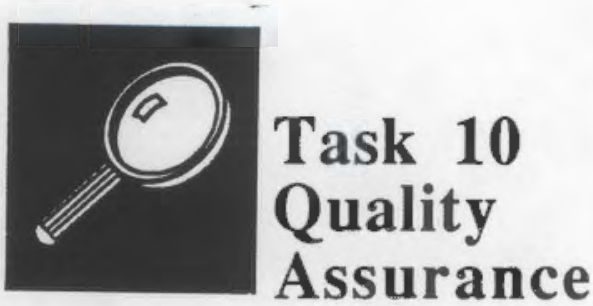

\section{Objective}

The objective of this task is to ensure continuous quality assurance (QA) support and coordination with all project tasks. This objective is met through the identification and documentation of QA requirements in the form of a QA Plan and periodic monitoring of project activities during the life of the project to ensure compliance with these requirements.

\section{Progress}

- met with key software code custodians/users to discuss appropriate software requirements necessary to manage key HEDR software

- continued meeting with key task leaders to check for compliance with the technical, QA, and data quality objective requirements

\section{Major Problem Areas or Changes and Action Taken}

None.

\section{Variance}

No significant cumulative variance.

\section{Planned Work for the Next Three Months}

- issue remaining HEDR procedure HEDR-TP-3, "HEDR Documentation of Critical Decisions"

- continue performing oversight activities to check for compliance with project technical, $\mathrm{QA}$, and data quality objective requirements

- prepare for the HEDR audit being planned by the Battelle internal audit group 



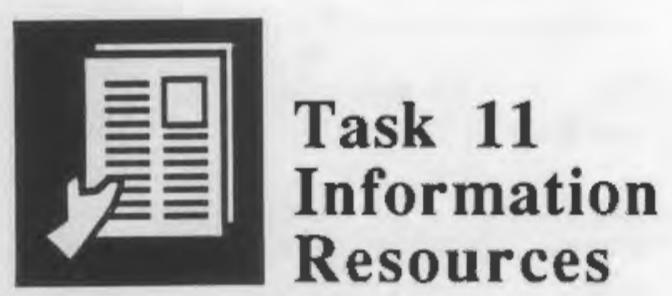

\section{Objective}

Members of the Information Resources Task work with the other task members to meet information needs, including ensuring that all data referenced in the reports are publicly available and establishing a microcomputer-based tracking system for ready retrieval of historical information.

\section{Progress}

\section{Information Resources Task Management (Subtask 1101)}

- received a letter from General Electric expressing their willingness to cooperate with us in identifying Hanford-originated documents describing historic operations or environmental issues. A title listing of General Electric's holdings in the Nuclear Energy Legal Operations file has been requested.

- At the request of the Westinghouse Hanford Company Legal Office and with approval of Battelle's Legal Office and the HEDR Project Office, S. Gydesen signed a declaration regarding Hanford Nuclear Litigation that was filed with the U.S. District Court, Eastem District of Washington, on July 24, 1991. This declaration details her knowledge of Hanfordoriginated documents and methods to retrieve them.

\section{Declassification (Subtask 1102)}

- The DOE-Headquarters Office of Classification has rescinded an earlier determination that cost information associated with producing plutonium and irradiating materials 1944-1960 is unclassified. This change will not affect HEDR needs.
- worked with M. Robkin (TSP), who spent one day on site reviewing classified documents, to identify those to be recommended for declassification review

- declassified 87 Hanford Site-originated documents, four of which are of potential interest use to the project. The remainder are from the TSP single-request prioritized listing and have not yet been reviewed by a TSP member; consequently, their value to HEDR is yet to be determined. Table 11.1 shows the status of declassification to date.

\section{Resource Identification and Availability (Subtask 1103)}

- added new citations to the tracking system that now contains more than 4,700 publications

- provided the RL Public Reading Room with 137 documents of potential interest/use in the HEDR Project. A title listing of these reports is given in Appendix B.

- provided B. Shleien (TSP) with numerous documents addressing radiation dosage delermination 
TABLE 11.1. Declassification by Task 11 Staff for the HEDR Project (1944-1960 Documents)

Document Type

Total Hanford Site documents (from

$1944-1960)$ as of $6 / 90$ that were classified

Subset of the 11,000 requested for declassifica-

tion by TSP, states, and interest groups

Number of documents from the approximately

1,450 requested for declassification by more than

1 person

Number of documents of the approximately 1,450 requested for declassification by single individuals

Number out of the 367 that were deemed to be of no interest to the public or the project, per TSP member M. Robkin

Multiple-request documents out of the 367 deemed useful for declassification by the TSP

Documents Declassified

March 1987 - September 1987

October 1987 through September 1988

October 1988 through September 1989

October 1989 through September 1990

October 1990 through July 1991

TOTAL (March 1987 - July 1991)
Number

11,000

2,000

1,066

131

236

All declassified; list in RL Public

Reading Room

Hanford Historical HEDR-Related(a)

35

27

52

37

186

177

455

236

$\underline{1242}$

$\underline{539}$

1970

(a) Reported in HEDR monthly reports and included in a HEDR master listing in the RL Public Reading Room. Some of these are from the list requested by the TSP and the public.

\section{RL Public Reading Room Activity}

- In July, the RL Reading Room had 15 HEDR users and distributed 31 HEDR reports
Major Problem Areas or Changes and Action Taken

None. 


\section{Variance}

No significant cumulative variance.

\section{Planned Work for the Next Three Months}

- continue to add input to the information resources tracking database and provide documents to the RL Public Reading Room in an orderly, timely fashion

- watch for information that may explain in detail, and support data in, "green run" document HW-17381 DEL

- identify significant documents that address fuel element failures that occurred in nowdecommissioned Hanford production reactors
- continue to develop "packing lists" for boxes of retired Hanford records of potential interest/use to the project

- identify and collect documents that address reactor purges, 1944-1971

- from the prioritized list of Hanford Siteoriginated classified documents, declassify, with or without deletions, those documents reviewed by $\mathrm{M}$. Robkin and identified as being of use to the project

- identify and retrieve daily operating data for all Hanford reactors, 1944-1971

- identify and retrieve data on ruthenium releases from separations processes 



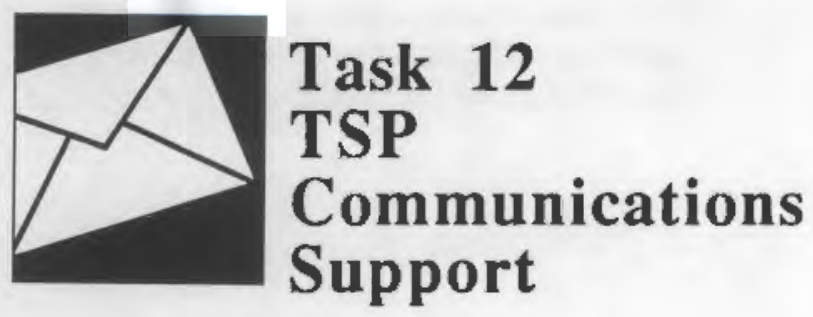

\section{Objective}

The objective of this task is to assist the TSP in developing and implementing communications strategies to further establish an effective, informative dialogue with interested audiences, provide public and media relations support, and manage activities that foster a better understanding of the HEDR process and its progress.

\section{Progress}

Milestone $1202 B$ - Videotape, due July 1991 and rescheduled to August 1991

- provided Battelle videoscript comments to TSP Communications Subcommittee

- signed contract with vendor (RXL Productions, Inc., Spokane, Washington) to produce TSP videotape. The subcontractor will provide video production services and edit to TSPdeveloped script. Vendor began videotaping during July TSP meeting in Pasco.

- assisted in search of historical photos of Hanford facilities and operations. Photos will be reproduced from archived negatives and used in the video production.

\section{Milestone 1203A - Letter Report on} Communications Assessment Research, due June 1991 and rescheduled to August 1991

- participated in a debriefing of Washington State University researchers who conducted the telephone sampling during June and July. Information learned is expected to assist the
TSP Communications Subcommittee in interpreting findings. A summary of results will be provided to the TSP Communications Subcommittee in August.

\section{Other Activities}

- in response to requests, provided HEDR Project information to citizens from San Diego, California; Richland, Washington; and Philadelphia, Pennsylvania. Referred them to the TSP toll-free telephone information line for additional materials and mailing list registration

- presented a status report on video contract progress, as well as the communications assessment survey, during the Communications Subcommittee meeting at the July TSP meeting in Pasco

\section{Major Problem Areas or Changes and Action Taken}

None. 


\section{Variance}

A cost underrun resulted from delays in videotape development and communications assessment research activities. This underrun is expected to be absorbed as the activities regain their full momentum during August and September.

\section{Planned Work for the Next Three}

Months

- assist in production and completion of the TSP videotape
- attend the August Communications Subcommittee meeting in Portland

- receive and present a summary of communications assessment survey results to the TSP Communications Subcommittee in August $\square$ 
Appendix A

Milestones, Schedule and Costs 


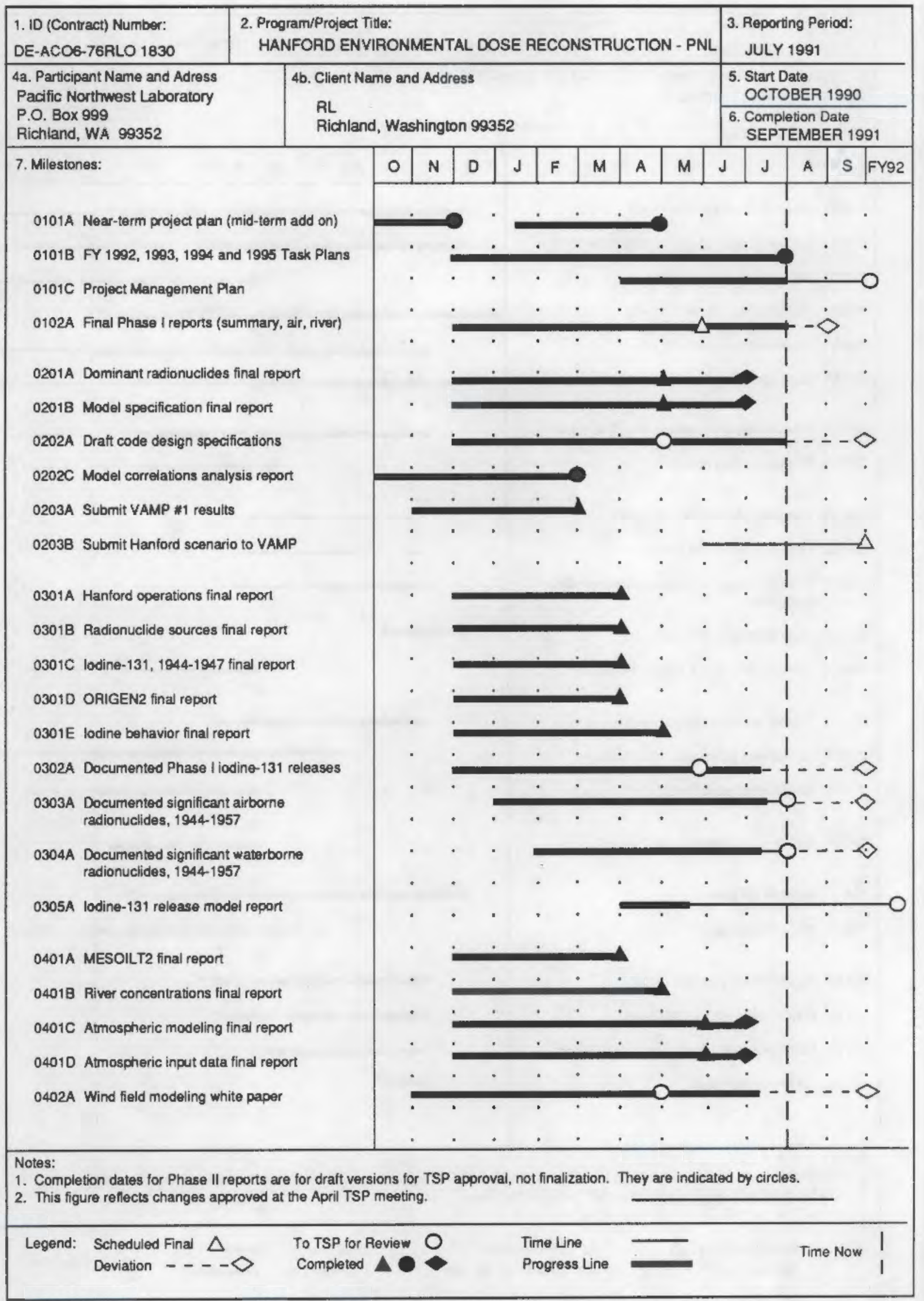

FIGURE A.1. HEDR Project Milestones

A. 1 


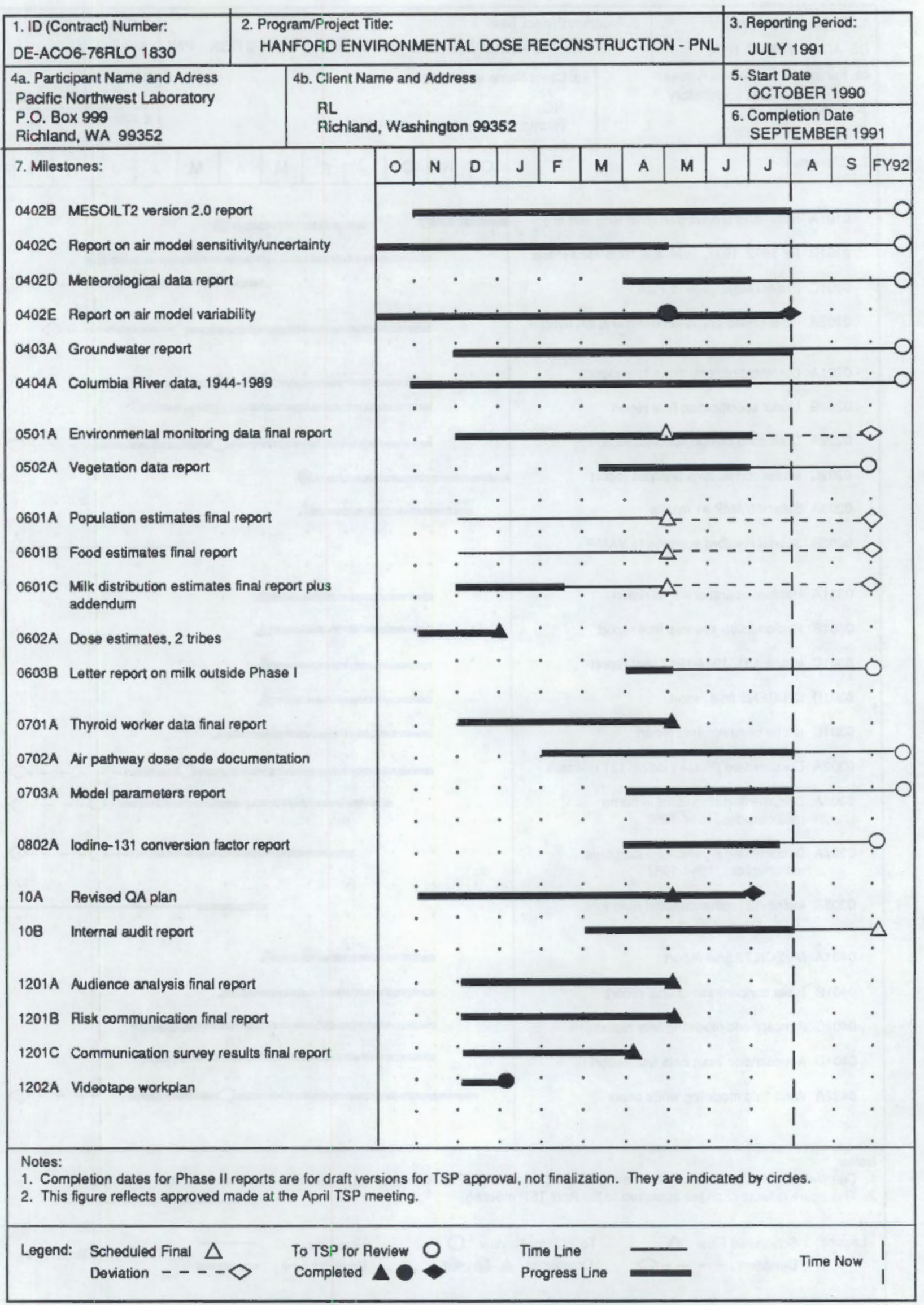

FIGURE A.1. HEDR Project Milestones (contd) 


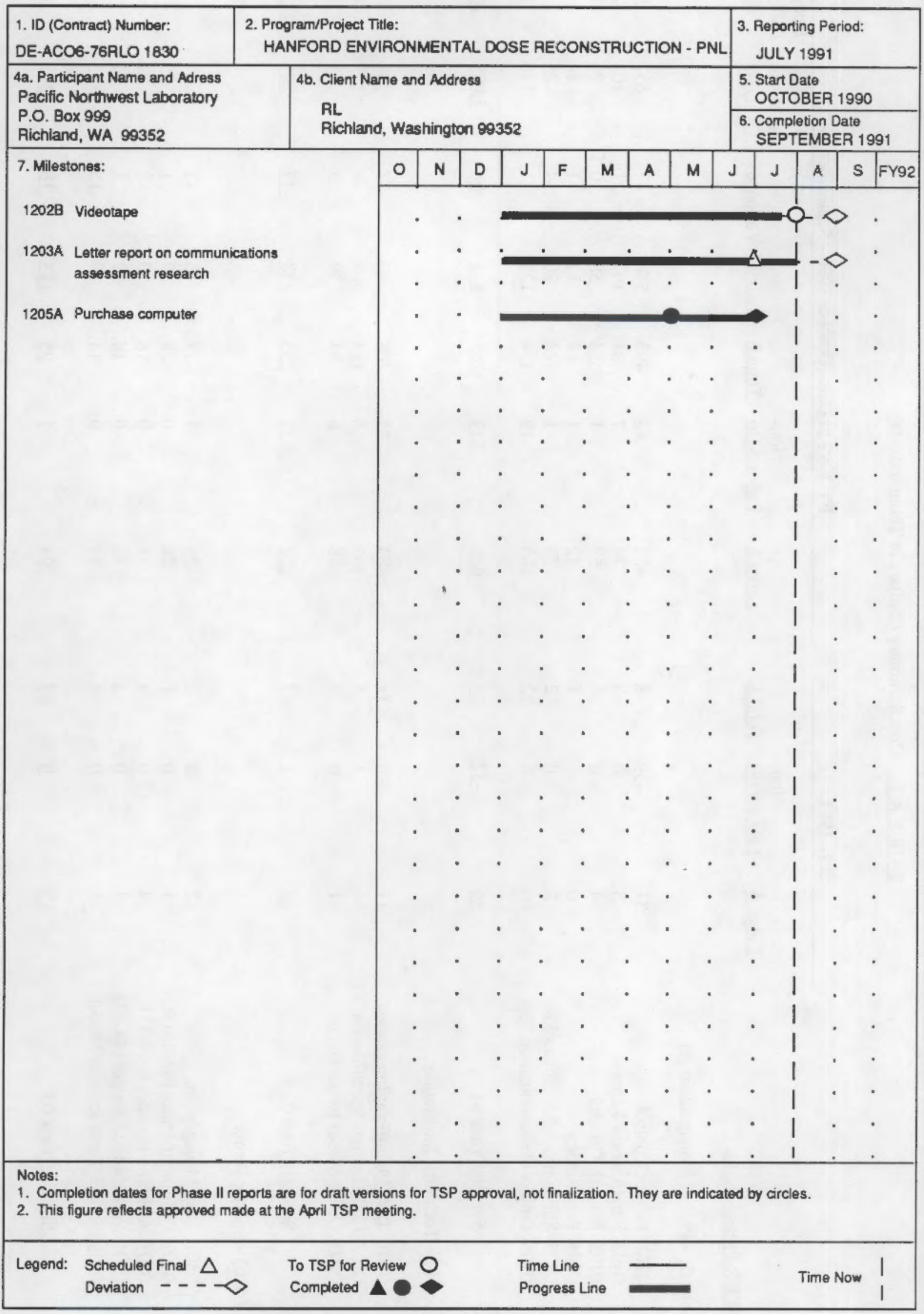

FIGURE A.1. HEDR Project Milestones (contd) 
TABLE A.1. Cost Summary (Dollars in Thousands) (a)

July 1991

\section{HEDR Project Tasks}

Task 01 - Project Management (c)

0101 Project Control

0102 Final Phase I Reports

0103 Records Control

0104 Peer Review

0105 Subcontract Administration

0106 Project Communication Sup

Subtotal Task 01

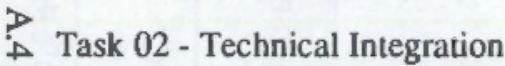

0201 Task Mgmu/Proj Integration

0202 Code Design Specification

0203 IAEA Model Intercompar.

Subtotal Task 02

Task 03 - Source Terms

0301 Task Management

0302 Closure of Phase I Iodine Re

0303 Airborne Isotopes not I-131

0304 Waterborne Isotopes (44-57)

0305 Source Term Release Model

Subtotal Task 03

2

56

\section{Non-}

Labor\$ Labor\$(b) Total
FY 1991 to Date (October 1990 - September 1991)

\begin{tabular}{|c|c|c|c|c|}
\hline Labor $\$$ & $\begin{array}{c}\text { Non- } \\
\text { Labor \$(b) Total \$ }\end{array}$ & $\begin{array}{r}\text { Cum } \\
\text { Budget }\end{array}$ & $\begin{array}{r}\text { Cum } \\
\text { Variance }\end{array}$ & $\begin{array}{r}\text { TSP } \\
\text { Approved } \\
\text { FY Budget }\end{array}$ \\
\hline
\end{tabular}

\begin{tabular}{rrr}
-39 & -8 & 405 \\
0 & 3 & 74 \\
0 & 4 & 57 \\
1 & 1 & 12 \\
0 & 2 & 23 \\
6 & 22 & 105 \\
-32 & $\underline{24}$ & $\underline{676}$ \\
\hline
\end{tabular}

\begin{tabular}{rr}
88 & 493 \\
7 & 8 \\
1 & 5 \\
1 & 13 \\
1 & 24 \\
19 & 12 \\
\hline
\end{tabular}

\section{6 \\ 102}

58

12
20

$\underline{117}$

793

$\underline{851}$

43
21

43
21

0

$-1$

$-4$

123

$-1$

58

$637 \quad 5,883$

$102 \quad 991$

70

411

1,489

10.322

\begin{tabular}{rrrrrr}
25 & 108 & 90 & -18 & 105 & 920 \\
6 & 113 & 109 & -4 & 129 & 1,186 \\
6 & 34 & 39 & 5 & 51 & 370 \\
37 & $\underline{255}$ & $\underline{238}$ & $\underline{-17}$ & $\underline{285}$ & $\underline{2.476}$ \\
\hline
\end{tabular}

218

83

107

28

117

218

37 255

$\underline{238}$

(1)

2.476

16

28

18

18

14

24

$\begin{array}{ll}1 & 17 \\ 0 & 28 \\ 0 & 18 \\ 0 & 18 \\ 0 & 14\end{array}$

$\begin{array}{rrrr}16 & -1 & 20 & 165 \\ 29 & 1 & 29 & 253 \\ 20 & 2 & 22 & 128 \\ 19 & 1 & 22 & 128 \\ 29 & 15 & 55 & 419 \\ \underline{113} & \underline{18} & \underline{148} & \underline{1.093}\end{array}$


TABLE A.1. Cost Summary (Dollars in Thousands) (a)

July 1991

Non-

Labor \$ Labor \$(b) Tolal \$
FY 1991 to Date (October 1990 - September 1991)

Non- Cum Cum Approved FY Labor

Labor $\$$ Labor $\$(D)$ Tolal $\$$ Budgel Variance EYBudgel Hours

Task 04 - Environmental Transport

\section{Task Management}

0402 Atmospheric Transport

0403 Groundwater Transport

0404 Surface Waler Transport

Subtotal Task 04

$\begin{array}{rrr}4 & 0 & 4 \\ 26 & 0 & 26 \\ 9 & 0 & 9 \\ 15 & 0 & 15 \\ \underline{54} & \underline{0} & \underline{54}\end{array}$

34
212
43
64
$\underline{3} 53$

1
15
3

35
227
46
67

$\underline{22} \quad \underline{375} \quad \underline{447}$

$\begin{array}{r}34 \\ 257 \\ 59 \\ 97 \\ 447 \\ \hline\end{array}$

-1
30
13
30

72

\begin{tabular}{rr}
42 & 400 \\
302 & 3,544 \\
59 & 654 \\
142 & 1,771 \\
& \\
545 & $\underline{6,369}$ \\
\hline
\end{tabular}

Task 05 - Environmental Monitoring Dala

in

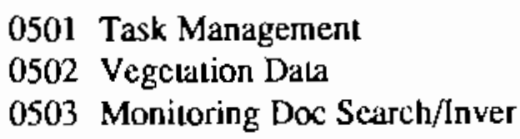

Subtotal Task 05

Task 06 - Demographics, Food Consumption, \& Agriculture

0601 Task Management

0602 Prelim Native American Data

0603 Milk Model Refinements

2
8
1

Subtotal Task 06

$\underline{11}$

$\underline{10}$

$\begin{array}{rrrrrr}0 & 0 & 0 & 0 & 0 & 0 \\ 0 & 35 & 47 & 12 & 62 & 405 \\ 0 & 1 & 6 & 5 & 10 & 139 \\ 0 & 36 & 53 & 17 & 72 & 544\end{array}$

221

$0 \quad 15 \quad 36$

0
35

1

36

24

$5 \quad 13$

29

101

4
-2
4

61

$\begin{array}{rr}33 & 26 \\ 69 & 190 \\ 5 & \\ & \end{array}$

$07 \quad 25$ 
TABLE A.1. Cusl Summary (Dollars in Thuusands) (a)

July 1991

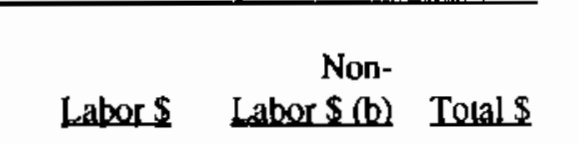

Labor $\$$ Labor $\$(b)$ Tolal $\$$

Task 07 - Environmental Pathways \& Dose Estimates

\begin{abstract}
0701 Task Management
0702 Code Restructure

HTDS Doses (d)

0703 Model Parameters
\end{abstract}

Subtotal Task 07

Task 08 - Stalistics

0801 Task Management

0802 Task Assistance

Subtolal Task 08

Task 09 - Records Management

Task 10 - Quality Assurance

Task 11 - lnformation Resources

1101 Task Management

1102 Declassification

1103 Resource Identification/Avail

Subtotal Task 11

\begin{tabular}{rrr}
5 & 0 & 5 \\
15 & 1 & 16 \\
0 & 0 & 0 \\
2 & 0 & 2 \\
22 & 1 & $\underline{23}$ \\
\hline
\end{tabular}

5

10

$\underline{15}$

3

1

2
1
6

2
FY 1991 to Date (October 1990 - September 1991)

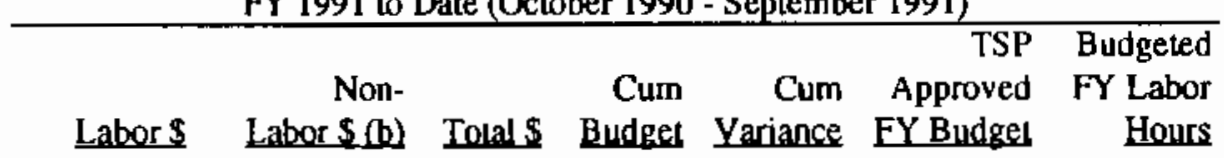

\begin{tabular}{lll}
1 & 3 & 17 \\
0 & 1 & 38 \\
0 & 6 & 56 \\
\hline
\end{tabular}

\begin{tabular}{rr}
1 & 18 \\
1 & 39 \\
1 & 57 \\
3 & 114 \\
\hline
\end{tabular}

$\begin{array}{rrrr}15 & -3 & 21 & 208 \\ 41 & 2 & 46 & 1,584 \\ 59 & 2 & 79 & 1,462 \\ 115 & 1 & 146 & \underline{3254}\end{array}$


TABLEA.1. Cost Summary (Dollars in Thousands) (a)

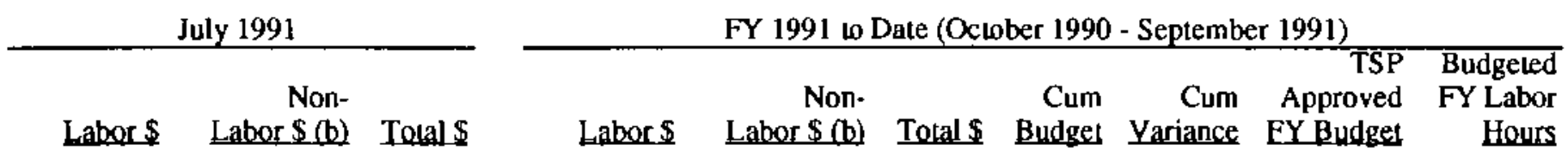

Task 12 - TSP Communications Support

1201 Task Management

1202 Video

1203 Com Assessment Research

1204 TSP Com Subcom Suppor

1205 TSP Dalabase/AV Suppon

Subtotal - Task 12

Subtotal, HEDR Project Tasks

$?$

\section{Subtotal, Project Tasks Plus \\ Contingency}

Technical Sleering Panel (f)

TOTAL

$\begin{array}{rrrr}1 & 1 & 2 & 17 \\ 1 & 0 & 1 & 4 \\ 0 & 0 & 0 & 6 \\ 0 & 2 & 2 & 4 \\ 0 & 3 & 3 & 0 \\ 2 & 6 & 8 & 31 \\ 217 & -15 & 202 & 1,880 \\ & & & \\ 217 & -15 & 202 & 1,880 \\ & & & 0 \\ 0 & \underline{20} & \underline{20} & \\ 217 & 5 & 222 & 1,880\end{array}$

1,880

31
17

2

$4-3$

14

2

22

2,10

$20 \quad 31$

$6 \quad 29$

644

7

14

16
16

11

23

38

9

$53 \quad 136$

83

2,510

403

3,061

32,699

$12 \quad \underline{12} \quad \underline{23}$

3,084

(a) Table reflects FY 1991 budget adjustments approved at the July, 1991 TSP mecting.

(b) Non-Labor dollars include expenses such as travel, publication production, procurements, and subcontracts.

(c) Project management includes activities such as project control and administration, project communications, subcontract administration, records control, and peer review.

(d) Funding reallocated by the TSP at the April TSP meeting.

(c) Budget not yet allocated.

(f) TSP costs are administered through subcontracts which are reflected as non-labor costs. Actual TSP expenses include both labor and non-labor. 


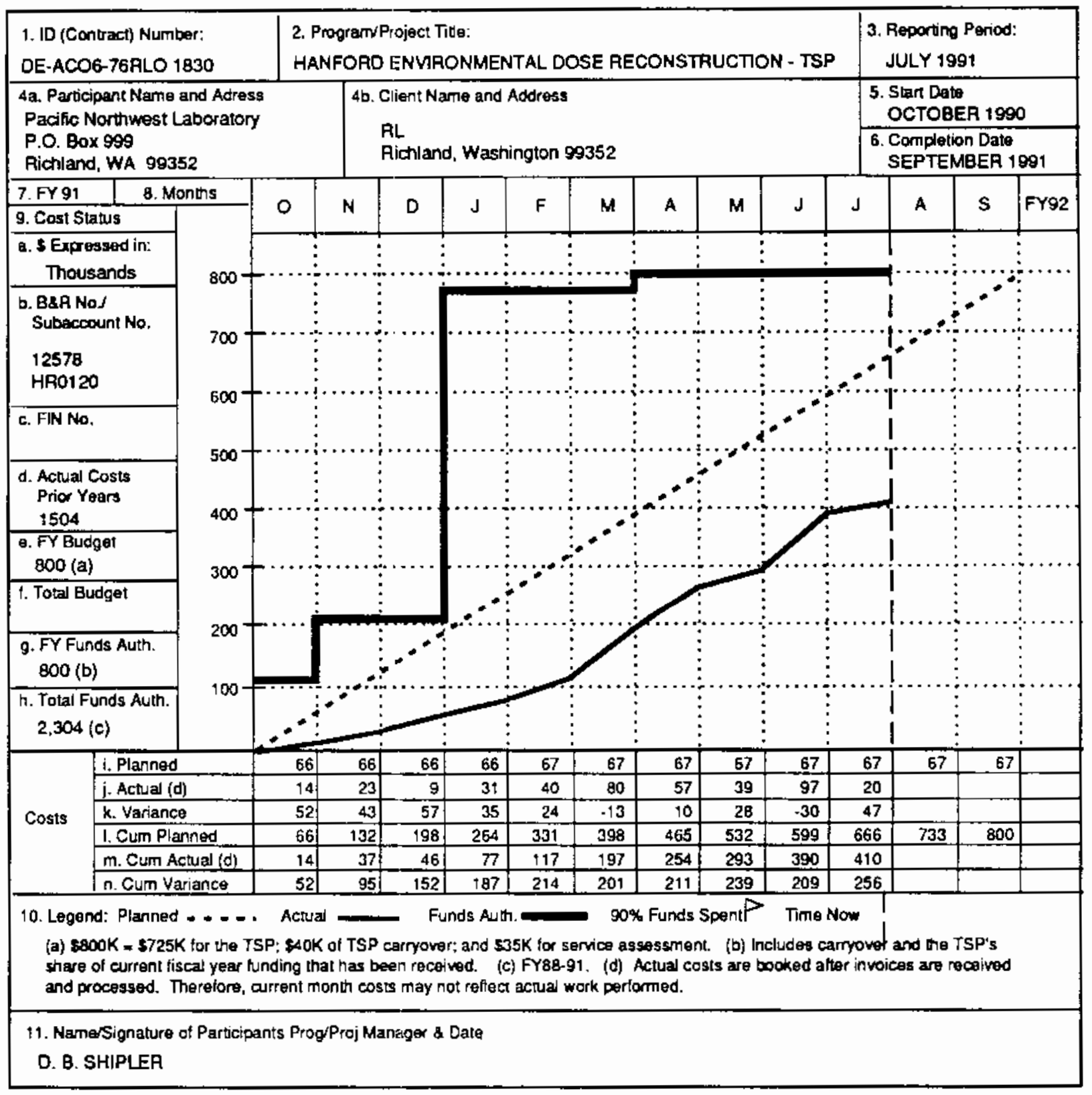

FIGURE A.2. Technical Steering Panel Budget Status 


\section{Appendix B \\ Hanford Site-Originated Documents of Potential Interest/Use to the HEDR Project - Placed in the RL Public Reading Room During July 1991}




\section{Appendix B}

Hanford Site-Originated Documents of Potential Interest/Use to the HEDR Project Placed in the RL Public Reading Room During July 1991

- HAN-35381

- HAN-35550

- HAN-35851

- HAN-36082

- HAN-36265

- HAN-36821

- HAN-36972

- HAN-37275

- HAN-37443

- HAN-37736

- HAN-38001

- HAN-40145

- HAN-40269

- HAN-40549

- HAN-40741

- HAN-40918
DATA ON KRYPTON-85 RELEASE AT HANFORD $2 \mathrm{p}$.

DATA ON KRYPTON-85 RELEASE AT HANFORD $2 \mathrm{p}$.

DATA ON KRYPTON-85 RELEASE AT HANFORD 2 p.

DATA ON KRYPTON-85 RELEASE AT HANFORD $2 \mathrm{p}$.

DATA ON KRYPTON-85 RELEASE AT HANFORD $2 \mathrm{p}$.

DATA ON KRYPTON-85 RELEASE AT HANFORD $2 \mathrm{p}$.

DATA ON KRYPTON-85 RELEASE AT HANFORD $2 \mathrm{p}$.

DATA ON KRYPTON-85 RELEASE AT HANFORD $2 \mathrm{p}$.

DATA ON KRYPTON-85 RELEASE AT HANFORD $2 \mathrm{p}$.

DATA ON KRYPTON-85 RELEASE AT HANFORD 2 p.

DATA ON KRYPTON-85 RELEASE AT HANFORD $2 \mathrm{p}$.

DATA ON KRYPTON-85 RELEASE AT HANFORD $2 \mathrm{p}$.

DATA ON KRYPTON-85 RELEASE AT HANFORD 2 p.

DATA ON KRYPTON-85 RELEASE AT HANFORD 2 p.

DATA ON KRYPTON-85 RELEASE AT HANFORD 2 p.

DATA ON KRYPTON-85 RELEASE AT HANFORD $2 \mathrm{p}$.
$01 / 04 / 51$

$01 / 19 / 51$

$02 / 06 / 51$

$02 / 20 / 51$

$03 / 05 / 51$

$04 / 04 / 51$

$04 / 18 / 51$

$05 / 04 / 51$

$05 / 18 / 51$

$06 / 06 / 51$

$06 / 21 / 51$

$07 / 10 / 51$

$07 / 18 / 51$

$08 / 06 / 51$

$08 / 21 / 51$

$09 / 06 / 51$

\section{B. 1}




\section{Appendix B}

Hanford Site-Originated Documents of Potential Interes/Use to the HEDR Project Placed in the RL Public Reading Room

During July 1991

- HAN-41034

- HAN-41279

- HAN-41533

- HAN-41696

- HAN-41864

- HAN-42084

- HAN-42279

- $\mathrm{HAN}-42558$

- HAN-42803

- HAN-43102

- HAN-43291

- HAN-43561

- HAN-43761

- HAN- 44002

- HAN-44253

- HAN-44518
DATA ON KRYPTON-85 RELEASE AT HANFORD $2 \mathrm{p}$.

DATA ON KRYPTON-85 RELEASE AT HANFORD 2 p.

DATA ON KRYPTON-85 RELEASE AT HANFORD $2 \mathrm{p}$.

DATA ON KRYPTON-85 RELEASE AT HANFORD 2 p.

DATA ON KRYPTON-85 RELEASE AT HANFORD 2 p.

DATA ON KRYPTON-85 RELEASE AT HANFORD 2 p.

DATA ON KRYPTON-85 RELEASE AT HANFORD 2 p.

DATA ON KRYPTON-85 RELEASE AT HANFORD 2 p.

DATA ON KRYPTON-85 RELEASE AT HANFORD $2 \mathrm{p}$.

DATA ON KRYPTON-85 RELEASE AT HANFORD 2 p.

DATA ON KRYPTON-85 RELEASE AT HANFORD 2 p.

DATA ON KRYPTON-85 RELEASE AT HANFORD 2 p.

DATA ON KRYPTON-85 RELEASE AT HANFORD 2 p.

DATA ON KRYPTON-85 RELEASE AT HANFORD $2 \mathrm{p}$.

DATA ON KRYPTON-85 RELEASE AT HANFORD 2 p.

DATA ON KRYPTON-85 RELEASE AT HANFORD 2 p.
$09 / 18 / 51$

$10 / 05 / 51$

$10 / 19 / 51$

$11 / 06 / 51$

$11 / 20 / 51$

$12 / 05 / 51$

$12 / 19 / 51$

$01 / 05 / 52$

$01 / 18 / 52$

$02 / 07 / 52$

$02 / 20 / 52$

$03 / 05 / 52$

$03 / 20 / 52$

$04 / 04 / 52$

$04 / 22 / 52$

$05 / 05 / 52$ 


\section{Appendix B}

Hanford Site-Originated Documents of Potential Interest/Use to the HEDR Project Placed in the RL Public Reading Room During July 1991

\begin{tabular}{|c|c|c|}
\hline - HAN-44715 & $\begin{array}{l}\text { DATA ON KRYPTON-85 REILASE AT } \\
\text { HANFORD } 2 \mathrm{p} .\end{array}$ & $05 / 21 / 52$ \\
\hline - HAN 44997 & $\begin{array}{l}\text { DATA ON KRYPTON-85 RELEASE AT } \\
\text { HANFORD } 2 \text { p. }\end{array}$ & $06 / 06 / 52$ \\
\hline - HAN-45135 & $\begin{array}{l}\text { DATA ON KRYPTON-85 RELEASE AT } \\
\text { HANFORD } 1 \text { p. }\end{array}$ & $06 / 18 / 52$ \\
\hline - HAN-45429 & $\begin{array}{l}\text { DATA ON KRYPTON-85 RELEASE AT } \\
\text { HANFORD } 1 \mathrm{p} .\end{array}$ & $06 / 07 / 52$ \\
\hline - HAN-45656 & $\begin{array}{l}\text { DATA ON KRYPTON-85 RELEASE AT } \\
\text { HANFORD } 2 \mathrm{p} .\end{array}$ & $07 / 18 / 52$ \\
\hline - HAN-45988 & $\begin{array}{l}\text { DATA ON KRYPTON-85 RELEASE AT } \\
\text { HANFORD } 2 \text { p. }\end{array}$ & $08 / 06 / 52$ \\
\hline - HAN-46382 & $\begin{array}{l}\text { DATA ON KRYPTON-85 RELEASE AT } \\
\text { HANFORD } 2 \mathrm{p} .\end{array}$ & $08 / 20 / 52$ \\
\hline - HAN-46524 & $\begin{array}{l}\text { DATA ON KRYPTON-85 RELEASE AT } \\
\text { HANFORD } 2 \text { p. }\end{array}$ & $09 / 02 / 52$ \\
\hline - $\mathrm{HAN}-46632$ & $\begin{array}{l}\text { DATA ON KRYPTON-85 RELEASE AT } \\
\text { HANFORD } 2 \text { p. }\end{array}$ & $09 / 18 / 52$ \\
\hline - HAN-46938 & $\begin{array}{l}\text { DATA ON KRYPTON-85 REIEASE AT } \\
\text { HANFORD } 2 \text { p. }\end{array}$ & $10 / 07 / 52$ \\
\hline${ }^{*} \mathrm{HW}-17660-\mathrm{A}$ & $\begin{array}{l}\text { P DIVISION MONTHLY REPORT APRIL, } \\
95011 \mathrm{p} .\end{array}$ & $05 / 04 / 50$ \\
\hline * HW-17971-A & $\begin{array}{l}\text { P DIVISION MONTHLY REPORT MAY } 1950 \\
11 \mathrm{p} .\end{array}$ & $06 / 06 / 50$ \\
\hline HW-19032 & $\begin{array}{l}\text { OPERATION INCIDENTS } \\
4 \mathrm{p} .\end{array}$ & $06 / 05 / 56$ \\
\hline * HW-19577 & $\begin{array}{l}\text { SKULL RECOVERY FACILITIES FOR } \\
\text { BULDING } 234-58 \mathrm{p} .\end{array}$ & $12 / 01 / 50$ \\
\hline *HW-20278-RD & $\begin{array}{l}\text { QUARTERLY REPORT-OCTOBER } 1949 \text { THRU } \\
\text { DECEMBER } 1950 \text { AQUATIC BIOLOGY } \\
\text { GROUP ROUGH DRAFT } 32 \mathrm{p} .\end{array}$ & $01 / 16 / 51$ \\
\hline
\end{tabular}




\section{Appendix B}

Hanford Site-Originated Documents of Potential Interest/Use to the HEDR Project Placed in the RL Public Reading Room During July 1991

HW-21497

P-10 PROJECT: LOSSES TO ATMOSPHERE

$06 / 02 / 51$

3 p.

- HW-26025

DATA ON KRYPTON-85 RELEASE AT

$10 / 23 / 52$ HANFORD 2 p.

- HW-26054

DATA ON KRYPTON-85 RELEASE AT

$10 / 28 / 52$

$\cdot$ HW-26251 HANFORD 1 p.

DATA ON KRYPTON-85 RELEASE AT HANFORD 2 p.

$11 / 17 / 52$

- HW-26407

DATA ON KRYPTON-85 RELEASE AT HANFORD 2 p.

$11 / 28 / 52$

• HW-26587

DATA ON KRYPTON-85 RELEASE AT

$12 / 17 / 52$ HANFORD 2 p.

* HW-26710

DATA ON KRYPTON-85 RELEASE AT HANFORD $2 \mathrm{p}$.

$12 / 31 / 52$

- HW-26871

DATA ON KRYPTON-85 RELEASE AT HANFORD 3 p.

$01 / 20 / 53$

- HW-27012

DATA ON KRYPTON-85 RELEASE AT

$02 / 02 / 53$ HANFORD 2 p.

$02 / 11 / 53$

HANFORD 2 p.

- HW-27547

DATA ON KRYPTON-85 RELEASE AT HANFORD $3 \mathrm{p}$.

$03 / 27 / 53$

- HW-27600

DATA ON KRYPTON-85 RELEASE AT HANFORD 2 p.

$04 / 01 / 53$

- HW-27732

DATA ON KRYPTON-85 RELEASE AT HANFORD 2 p.

$04 / 15 / 53$

- HW-28018

DATA ON KRYPTON-85 RELEASE AT

$05 / 11 / 53$ HANFORD $2 \mathrm{p}$.

$05 / 21 / 53$

DATA ON KRYPTON-85 RELEASE AT HANFORD $3 \mathrm{p}$.

$06 / 02 / 53$

DATA ON KRYPTON-85 RELEASE AT HANFORD $2 \mathrm{p}$. 


\section{Appendix B}

Hanford Site-Originated Documents of Potential Interest/Use to the HEDR Project -

Placed in the RL Public Reading Room

During July 1991

- HW-28376

- HW-28708

$\cdot$ HW-28768

- HW-28863

- HW-29101

- HW-29379

- HW-29444

- HW-2966I

- HW-29668

- HW-29985

- HW-30145

- HW-30871

- HW-30872

- HW-30873

- HW-31074

- HW-31362
DATA ON KRYPTON-85 RELEASE AT HANFORD 2 p.

DATA ON KRYPTON-85 RELEASE AT HANFORD 2 p.

DATA ON KRYPTON-85 RELEASE AT HANFORD $3 \mathrm{p}$.

DATA ON KRYPTON-85 RELEASE AT HANFORD 2 p.

DATA ON KRYPTON-85 RELEASE AT HANFORD 3 p.

DATA ON KRYPTON-85 REIEASE AT HANFORD $2 \mathrm{p}$.

DATA ON KRYPTON-85 RELEASE AT HANFORD 3 p.

DATA ON KRYPTON-85 RELEASE AT HANFORD $2 \mathrm{p}$.

DATA ON KRYPTON-85 RELEASE AT HANFORD 2 p.

HANFORD RELEASE CALCULATIONS

$3 \mathrm{p}$.

HANFORD RELEASE CALCULATIONS 3 p.

HANFORD RELEASE CALCULATIONS

3 p.

HANFORD RELEASE CALCULATIONS 3 p.

HANFORD RELEASE CALCULATIONS

$5 \mathrm{p}$.

HANFORD RELEASE CALCULATIONS

4 p.

HANFORD RELEASE CALCULATIONS 4 p.
$06 / 12 / 53$

$07 / 14 / 53$

$07 / 22 / 53$

$07 / 28 / 91$

$08 / 21 / 53$

$09 / 17 / 53$

$09 / 25 / 53$

$10 / 16 / 53$

$10 / 19 / 53$

$11 / 13 / 53$

$12 / 01 / 53$

$02 / 16 / 54$

$02 / 17 / 54$

$02 / 18 / 54$

$03 / 10 / 54$

$04 / 06 / 54$ 


\section{Appendix B}

Hanford Site-Originated Documents of Potential Interest/Use to the HEDR Project Placed in the RL Public Reading Room

During July 1991

- HW-31659

- HW-31975

* HW-32784

* HW-32889-E

- HW-32920

- HW-33875

- HW-34044

- HW-35181

- HW-35668

- HW-36051

* HW-36424

- HW-36727

* HW-36929

- HW-37495

* HW-38375-E
HANFORD RELEASE CALCULATIONS

$4 \mathrm{p}$.

HANFORD RELEASE CALCULATIONS 4 p.

PROGRESS REPORT EARTH SCIENCES GROUND WATER MONITORING ACTIVITIES $10 \mathrm{p}$.

RADIOLOGICAL SCIENCES DEPT RPT FOR MONTH OF AUGUST $195414 \mathrm{p}$.

HANFORD RELEASE CALCULATIONS

7 p.

HANFORD RELEASE CALCULATIONS 7 p.

HANFORD RELEASE CALCULATIONS

$4 \mathrm{p}$.

HANFORD RELEASE CALCULATIONS

7 p.

HANFORD RELEASE CALCULATIONS $2 \mathrm{p}$.

HANFORD RELEASE CALCULATIONS

$3 \mathrm{p}$.

RAD SCI DEPT - RADIATION MONITORING UNIT MONTHL Y REPORT FOR APRIL 1955 $17 \mathrm{p}$.

HANFORD RELEASE CALCULATIONS $3 \mathrm{p}$.

RAD SCI DEPT - RADIATION MONITORING UNTT MONTHLY REPORT FOR MAY 1955 $16 \mathrm{p}$.

HANFORD RELEASE CALCULATIONS $5 \mathrm{p}$.

RADIOLOGICAL SCIENCES DEPT RPT FOR MONTH OF JULY 19559 p.
$09 / 06 / 54$

$06 / 23 / 55$

$04 / 29 / 54$

$05 / 28 / 54$

$07 / 30 / 54$

$09 / 01 / 54$

$11 / 23 / 55$

$12 / 07 / 54$

$02 / 11 / 55$

$03 / 08 / 55$

$04 / 04 / 55$

$04 / 29 / 55$

$05 / 16 / 55$

$05 / 31 / 55$

$08 / 05 / 55$

B. 6 


\section{Appendix B}

Hanford Site-Originated Documents of Potential Interest/Use to the HEDR Project Placed in the RL Public Reading Room During July 1991

\begin{tabular}{|c|c|c|}
\hline - HW-39251 & $\begin{array}{l}\text { HANFORD RELEASE CALCULATIONS } \\
1 \text { p. }\end{array}$ & $09 / 29 / 55$ \\
\hline - HW-39606 & $\begin{array}{l}\text { HANFORD RELEASE CALCULATIONS } \\
1 \text { p. }\end{array}$ & $10 / 21 / 55$ \\
\hline * HW-40188 & $\begin{array}{l}\text { RADIOLOGICAL SCIENCES DEPT MONTHLY } \\
\text { SECTION REPORTS NOVEMBER } 1955 \\
30 \mathrm{p} .\end{array}$ & $12 / 05 / 55$ \\
\hline * HW-40693 & $\begin{array}{l}\text { RADIOLOGICAL SCIENCES DEPT MONTHLY } \\
\text { SECTION RPTS DECEMBER } 1955 \\
27 \mathrm{p.}\end{array}$ & $01 / 06 / 56$ \\
\hline$* \mathrm{HW}-41205-\mathrm{E}$ & $\begin{array}{l}\text { RADIOLOGICAL SCIENCES DEPT REPORT } \\
\text { FOR MONTH OF JANUARY } 1956 \quad 8 \mathrm{p} .\end{array}$ & $02 / 06 / 56$ \\
\hline - HW-41382 & $\begin{array}{l}\text { HANFORD RELEASE CALCULATIONS } \\
1 \text { p. }\end{array}$ & $02 / 10 / 56$ \\
\hline - HW-41664 & $\begin{array}{l}\text { HANFORD RELEASE CALCULATIONS } \\
\text { I p. }\end{array}$ & $02 / 27 / 56$ \\
\hline * HW-42219-E & $\begin{array}{l}\text { RADIOLOGICAL SCIENCES DEPT REPORT } \\
\text { FOR MONTH OF MARCH } 19569 \mathrm{p} .\end{array}$ & $04 / 06 / 56$ \\
\hline${ }^{*} \mathrm{HW}-42626-\mathrm{E}$ & $\begin{array}{l}\text { RADIOLOGICAL SCIENCES DEPT REPORT } \\
\text { FOR MONTH OF APRIL } 19569 \mathrm{p} .\end{array}$ & $05 / 04 / 56$ \\
\hline * HW-42710 & $\begin{array}{l}\text { RSD - RADIATION MONITORING UNIT } \\
\text { MONTHLY REPORT APRIL } 195615 \mathrm{p} .\end{array}$ & $04 / 30 / 56$ \\
\hline * HW-42899 & $\begin{array}{l}\text { REACTOR SECTION RADLATION } \\
\text { MONITORING REPORT FOR MONTH OF } \\
\text { APRIL } 1956 \quad 10 \mathrm{p} .\end{array}$ & $05 / 01 / 56$ \\
\hline - $\mathrm{HW}-43072$ & $\begin{array}{l}\text { HANFORD RELEASE CALCULATIONS } \\
1 \mathrm{p} .\end{array}$ & $05 / 15 / 56$ \\
\hline * HW-43979 & $\begin{array}{l}\text { RADIOLOGICAL SCIENCES DEPT MONTHLY } \\
\text { SECTION REPORTS JUNE } 195632 \text { p. }\end{array}$ & $07 / 06 / 56$ \\
\hline * HW-44706 & $\begin{array}{l}\text { RADIOLOGICAL SCIENCES DEPT MONTHLY } \\
\text { SECTION REPORTS JULY } 195629 \mathrm{p} .\end{array}$ & $08 / 06 / 56$ \\
\hline * HW-45114 & $\begin{array}{l}\text { RADIOLOGICAL SCIENCES DEPT MONTHLY } \\
\text { SECTION REPORT AUGUST } 195628 \text { p. }\end{array}$ & $09 / 07 / 56$ \\
\hline
\end{tabular}

B.7 


\section{Appendix B}

Hanford Site-Originated Documents of Potential Interest/Use to the HEDR Project Placed in the RL Public Reading Room

During July 1991

* HW-45115-E

* HW-46368

* HW-47657

* HW-48842

- HW-49024

* HW-50586

- HW-51419

* HW-51750

* HW-52493

* HW-54022-RD

* HW-54408

* HW-54722

* HW-54750

* HW-55183

* HW-63765
RADIOLOGICAL SCIENCES DEPT REPORT FOR MONTH OF AUGUST $19567 \mathrm{p}$.

RADLATTON MONITORING REPORT OCTOBER $195621 \mathrm{p}$.

RADIATTON MONITORING OPERATION REPORT FOR DECEMBER $195620 \mathrm{p}$.

HANFORD LABS OPERATION REPORT FEBRUARY $19577 \mathrm{p}$.

CHEMICAL PROCESSING WASTE LOSS DATA $1 \mathrm{p}$.

RADIATION MONTTORING OPERATION REPORT FOR MAY $195718 \mathrm{p}$.

RECOVERY OF PLUTONIUM FROM STORED HANFORD WASTES $4 \mathrm{p}$.

PROJECT PROPOSAL - WATER PLANT EXPANSION-100KE AND KW 8 p.

$09 / 07 / 56$

$10 / 31 / 56$

$12 / 31 / 56$

$03 / 04 / 57$

$03 / 13 / 57$

$05 / 31 / 57$

$07 / 30 / 57$

$09 / 06 / 57$

$09 / 16 / 57$

CURRENT INVENTORY OF HANFORD WASTES

3 p.

WASTE STORAGE REQUIREMENTS FOR CHEMICAL PROCESSING DEPARTMENT $6 \mathrm{p}$.

$12 / 02 / 57$

RADLATION MONITORING OPERATTON

$12 / 31 / 57$ REPORT FOR DECEMBER 195712 p.

CHEMICAL PROCESSING DEPT PROCESS

WASTE STORAGE PERFORMANCE 1957

$4 \mathrm{p}$.

WASTE STORAGE REQUIREMENTS FOR CHEMICAL PROCESSING DEPT $7 \mathrm{p}$.

$01 / 28 / 58$

$03 / 27 / 58$

FILTERED WATER CROSS-TIE, 183-B AND 183-C -PROJECT PROPOSAL 11 p.

$01 / 27 / 58$

COLUMBLA RIVER SCALE MODEL

$11 \mathrm{p}$.

$02 / 12 / 60$ 


\section{Appendix B}

Hanford Site-Originated Documents of Potential Interest/Use to the HEDR Project Placed in the RL Public Reading Room

During July 1991

HW-89079

HW-89080

HW-89081

HW-SA-3073

* MED-1001

* MED-1002

* MED-1003

* MED-1004

PNL-7274-HEDR

PNL-7600-PT2

PNL-7600-PT3

PNL-7600-PT4
DAILY OPERATING CONDITIONS 100

AREAS (B,D,F \& H) OCTOBER 1948 -

DECEMBER $194959 \mathrm{p}$.

DAILY OPERATING CONDITIONS 100 AREAS $195064 \mathrm{p}$.

DAILY OPERATING CONDITIONS 100 AREAS $195172 \mathrm{p}$.

METABOLISM OF Te-132 - I-132 IN

LACTATING SHEEP $10 \mathrm{p}$.

100-F AREA PRE-START-UP LOGS -

DAILY DIARY $141 \mathrm{p}$.

100-B DAILY DIARY

$176 \mathrm{p}$.

100-D AREA DAILY DIARY

209 p.

100-B AREA DAILY DIARY

$141 \mathrm{p}$.

COMPUTATIONAL MODEL DESIGN SPECIFICATION FOR PHASE 1 OF THE HANFORD ENVIRONMENTAL DOSE RECONSTRUCTION PROJECT $53 \mathrm{p}$.

PACIFIC NORTHWEST LABORATORY ANNUAL REPORT FOR 1990 TO THE DOE OFFICE OF ENERGY RESEARCH $113 \mathrm{p}$.

PACIFIC NORTHWEST LABORATORY ANNUAL REPORT FOR 1990 TO THE DOE OFFICE OF ENERGY RESEARCH $45 \mathrm{p}$.

PACIFIC NORTHWEST LABORATORY ANNUAL REPORT FOR 1990 TO THE DOE OFFICE OF ENERGY RESEARCH $77 \mathrm{p}$.
$12 / 31 / 49$

$12 / 31 / 50$

$12 / 31 / 51$

$08 / 06 / 63$

$08 / 03 / 45$

$06 / 30 / 45$

$12 / 17 / 44$

$08 / 12 / 44$

$07 / 03 / 91$

$02 / 20 / 91$

$04 / 20 / 91$

$03 / 02 / 91$ 


\title{
Appendix B \\ Hanford Site-Originated Documents of Potential Interest/Use to the HEDR Project - \\ Placed in the RL Public Reading Room \\ During July 1991
}

PNL-7600-PT5

\author{
PACIFIC NORTHWEST LABORATORY ANNUAL \\ REPORT FOR 1990 TO THE ASSISTANT \\ SECRETARY FOR ENVIRONMENT, SAFETY, \\ HEALTH, AND QUALITY ASSURANCE \\ $55 \mathrm{p}$.
}

$05 / 2091$

- Declassified by Secretary of Energy Watkins' directive.

*Declassified in 1991 by earlier guidance. 


\section{ADDENDUM}

These documents on krypton-85 releases at Hanford were declassified in 1991 under the guidelines of Secretary of Energy Watkins' directive. They are not yet in the RL Public Reading Room. However, the data from these reports have been incorporated into HAN-62263, which is in the RL Public Reading Room in Richland, Washington.

These calculations were a part of the Atomic Energy Commission Department of Research and Development effort to estimate the amounts of radioactive noble gases released by Hanford operations. Noble gases such as krypton and xenon do not react with other materials; therefore, they remain in the atmosphere until they decay.

HAN-57166

HAN-57305

HAN-58010

HAN-58257

HAN-58689

HAN-59086

HAN-59474

HAN- 60376

HAN- 60625

HAN-61529

HAN-61652

HAN-62429
Hanford Release Calcularions

$11 / 23 / 54$

*

"

11

n

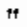

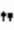

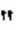

"

"

II
12/07/54

$02 / 11 / 55$

$03 / 08 / 55$

04/04/55

$05 / 16 / 55$

06/23/55

$09 / 29 / 55$

$10 / 21 / 55$

$02 / 10 / 56$

$02 / 27 / 56$

$05 / 15 / 56$ 


\section{Appendix C \\ HEDR Publications - July 1991}

Note: This appendix lists only publications that are new this month or have undergone some kind of change, such as being approved by the TSP. A complete list for FY 1991 will be included in the September 1991 report 
Appendix $C$

HEDR Publications - July 1991(a)

\begin{tabular}{|c|c|c|c|c|c|}
\hline Title & Author & $\begin{array}{l}\text { Date } \\
\text { Issued }\end{array}$ & $\begin{array}{c}\text { Publication } \\
\text { No. }\end{array}$ & Additional Information & Status \\
\hline $\begin{array}{l}\text { FY } 1992 \text { Task Plans for the Hanford } \\
\text { Environmental Dose Reconstruction } \\
\text { Project }\end{array}$ & Shipler, DB & $7 / 91$ & PNL-7757 HEDR & & $\begin{array}{l}\text { To TSP for } \\
\text { review } 7 / 91\end{array}$ \\
\hline $\begin{array}{l}\text { FY } 1993 \text { Task Plans for the Hanford } \\
\text { Environmental Dose Reconstruclion } \\
\text { Project }\end{array}$ & Shipler, DB & $7 / 91$ & PNL-7760 HEDR & & $\begin{array}{l}\text { To TSP for } \\
\text { review } 7 / 91\end{array}$ \\
\hline $\begin{array}{l}\text { FY } 1994 \text { Task Plans for the Hanford } \\
\text { Environmental Dose Reconstruclion } \\
\text { Project }\end{array}$ & Shipler, DB & $7 / 91$ & PNL-7759 HEDR & & $\begin{array}{l}\text { To TSP for } \\
\text { review } 7 / 91\end{array}$ \\
\hline $\begin{array}{l}\text { FY } 1995 \text { Task Plans for the Hanford } \\
\text { Environmental Dose Reconstruclion } \\
\text { Project }\end{array}$ & Shipler, DB & $7 / 91$ & PNL-7761 HEDR & & $\begin{array}{l}\text { To TSP for } \\
\text { review } 7 / 91\end{array}$ \\
\hline Air Pathway Report & HEDR staff & $7 / 91$ & PNL-7412 HEDR Rev. 1 & $\begin{array}{l}\text { Presents Phase I } \\
\text { results }\end{array}$ & $\begin{array}{l}\text { Approved by the } \\
\text { TSP and } \\
\text { published final } \\
7 / 91\end{array}$ \\
\hline Columbia River Palhway Report & HEDR Staff & $7 / 91$ & PNL-7411 HEDR Rev. 1 & $\begin{array}{l}\text { Presents Phase I } \\
\text { results }\end{array}$ & $\begin{array}{l}\text { Approved by the } \\
\text { TSP and } \\
\text { published fmal } \\
7 / 91\end{array}$ \\
\hline
\end{tabular}

(a) HEDR publications identified in Appendix C are available in the RL Public Reading Room within 30 days of the issuance of this repon. 


\begin{tabular}{|c|c|c|c|c|c|}
\hline Title & Author & $\begin{array}{l}\text { Date } \\
\text { Issued }\end{array}$ & $\begin{array}{c}\text { Publication } \\
\text { No. }\end{array}$ & Additional Information & Status \\
\hline $\begin{array}{l}\text { Selection of Dominant Radionuclides } \\
\text { for Phase I of the Hanford } \\
\text { Environmental Dose Reconstruction } \\
\text { Project }\end{array}$ & Napier, BA & $7 / 91$ & PNL-7231 HEDR & & $\begin{array}{l}\text { Approved by the } \\
\text { TSP and } \\
\text { published final in } \\
7 / 91\end{array}$ \\
\hline $\begin{array}{l}\text { Compulational Model Design } \\
\text { Specification for Phase I of the Hanford } \\
\text { Environmental Dose Reconsiruction } \\
\text { Project }\end{array}$ & Napier, BA & $7 / 91$ & PNL-7274 HEDR & & $\begin{array}{l}\text { Approved by the } \\
\text { TSP and } \\
\text { published final in } \\
7 / 91\end{array}$ \\
\hline $\begin{array}{l}\text { Dose Estimate Variability Caused by } \\
\text { Air Model Uncertainties }\end{array}$ & Simpson, JC & $7 / 91$ & PNL-7737 HEDR & & $\begin{array}{l}\text { To TSP for } \\
\text { review } 7 / 91\end{array}$ \\
\hline
\end{tabular}


Appendix D

HEDR Presentation Handouts to the TSP - July 1991 
Appendix D

HEDR Presentation Handouts to the TSP - July 1991

\begin{tabular}{llccl}
\multicolumn{1}{c}{ Title } & Author & $\begin{array}{c}\text { Date } \\
\text { Issued }\end{array}$ & $\begin{array}{c}\text { Publication } \\
\text { No. }\end{array}$ & Additional Information \\
\hline $\begin{array}{l}\text { Battelle Status of Technical } \\
\text { Work }\end{array}$ & Shipler, DB et al. & $7 / 91$ & $\begin{array}{l}\text { PNL-SA-19752S } \\
\text { HEDR }\end{array}$ & $\begin{array}{l}\text { Presented at he TSP neeting, } \\
\text { July 10-13, 1991, Pasco, WA }\end{array}$
\end{tabular}

D. 1 


\section{Appendix E \\ HEDR-Related Publications and Presentations - July 1991}

Note: This appendix lists publications (new this month) that present aspects of dose reconstruction in the open scientific literature; TSP approval is not required. A listing for FY 1991 will be included in the September 1991 report.

No HEDR-related publications or presentations were generated in July 1991. 
Appendix F

Communications Log - July 1991 


\begin{tabular}{|c|c|c|c|}
\hline $\begin{array}{c}\text { Initiated By/ } \\
\text { Affiliation }\end{array}$ & $\begin{array}{l}\text { Contact/ } \\
\text { Affiliation }\end{array}$ & Type & Subject \\
\hline DB Shipler/PNL & JS Stohr/TSP staff & Phone & Inter-tribal meeting agenda \\
\hline WA Bishop/TSP & DB Shipler/PNL & Phone & Tribal budget for FY 1992 \\
\hline R Brich/RL & DB Shipler/PNL & Phone & HEDR/CDC budget process \\
\hline JE Till/TSP & DB Shipler/PNL & Phone & Proposed scope and budget \\
\hline B Shleien/TSP & DB Shipler/PNL & Phone & Databases, funding \\
\hline R Brich/RL & DB Shipler/PNL & Phone & DOE funding process \\
\hline DB Shipler/PNL & M Sage/CDC & Phone & CDC/Battelle contracting process \\
\hline ML Blazek/TSP & DB Shipler/PNL & Phone & $\begin{array}{l}\text { HEDR air modeling vs. WNP-2 } \\
\text { modeling }\end{array}$ \\
\hline $\begin{array}{l}\text { DB Manders/ Wash. } \\
\text { Scate Dept. of Health }\end{array}$ & DB Shipler/PNL & Phone & Hanford information advisory board \\
\hline DB Shipler/PNL & R Brich/RL & Phone & $\begin{array}{l}\text { Hanford emergency planning and air } \\
\text { modeling }\end{array}$ \\
\hline DB Shipler/PNL & JE Till/TSP & Phone & $\begin{array}{l}\text { Dose cut-off, project schedule, } \\
\text { declassification }\end{array}$ \\
\hline B Shleien/TSP & DB Shipler/PNL & Phone & Scoping decisions and dose limit \\
\hline JE Till/TSP & DB Shipler/PNL & Phone & Project schedule review \\
\hline L Sewell/CDC & DB Shipler/PNL & Phone & $\begin{array}{l}\text { TSP workshop agenda, Native American } \\
\text { contracts }\end{array}$ \\
\hline JE Till/TSP & DB Shipler/PNL & Phone & Project schedule review and comments \\
\hline
\end{tabular}




\begin{tabular}{|c|c|c|c|}
\hline $\begin{array}{l}\text { Initiated By/ } \\
\text { Affiliation }\end{array}$ & $\begin{array}{l}\text { Contact/ } \\
\text { Affiliation }\end{array}$ & Type & Subject \\
\hline JM Daer/PNL & JS Stohr/TSP staff & Phone & $\begin{array}{l}\text { Transposed document numbers on } \\
\text { Phase I audience analysis report }\end{array}$ \\
\hline $\begin{array}{l}\text { Lowando/ Umarilla } \\
\text { Tribe }\end{array}$ & SM Finch/PNL. & Phone & $\begin{array}{l}\text { Contracts for attendance and reimbur- } \\
\text { sement for TSP meetings }\end{array}$ \\
\hline SM Finch/PNL & MA Robkin/TSP & Phone & Reinstated mag card \\
\hline B Shleien/TSP & SM Finch/PNL & Phone & Request for slides, workshop dates \\
\hline $\begin{array}{l}\text { DB Manders/ Wash. } \\
\text { State Dept. of Health }\end{array}$ & SM Finch/PNL & Phone & RFP for resource center \\
\hline JE Till/TSP & SM Finch/PNL & Phone & $\begin{array}{l}\text { Scope for FY } 1993 \text { task plan, letter on } \\
\text { Battelle policy }\end{array}$ \\
\hline B Shleien/TSP & SM Finch/PNL & Phone & $\begin{array}{l}\text { Slides, additional funding on } \\
\text { subcontrach, paper on scoping document } \\
\text { and dose cut-off limits }\end{array}$ \\
\hline S Walbreck/ FHCRC & SM Finch/PNI. & $\begin{array}{l}\text { Phone \& } \\
\text { fax }\end{array}$ & $\begin{array}{l}\text { Badging information for FHCRC staff } \\
\text { for meeting at PNL. }\end{array}$ \\
\hline AP Slickpoo/TSP & SM Finch/PNL & Phone & $\begin{array}{l}\text { Native American training session, } \\
\text { July } 29-30\end{array}$ \\
\hline WA Bishop/TSP & SM Finch/PNL & Phone & TSP funding \\
\hline IS Stohr/TSP staff & SM Finch/PNL & Phone & $\begin{array}{l}\text { Status of FY } 1991 \text { supplement, } \\
\text { invoices, justification for indirect } \\
\text { charges }\end{array}$ \\
\hline CM Heeb/PNL & $\begin{array}{l}\text { OH Greager/ retired Hanford } \\
\text { worker }\end{array}$ & Phone & $\begin{array}{l}\text { Experience in the early } 1944-1947 \\
\text { period, dissolver operations }\end{array}$ \\
\hline CM Heeb/PNL & $\begin{array}{l}\text { WK McCready/ retired } \\
\text { Hanford worker }\end{array}$ & Phone & $\begin{array}{l}\text { Experience in the early } 1944-1947 \\
\text { period, dissolver operations }\end{array}$ \\
\hline CM Heeb/PNL & $\begin{array}{l}\text { WK Wrigh/ retired Hanford } \\
\text { worker }\end{array}$ & Phone & $\begin{array}{l}\text { Experience in the early 1944-1947 } \\
\text { period, dissolver operations }\end{array}$ \\
\hline
\end{tabular}


CM Heeb/PNL

Reactor Shielding

Information

Center/ORNL

HA Haerer/Golder

HA Haerer/Golder

TA Ikenberry/ PNL

KJ Kopecky/TSP

D Powaukee/Nez Perce

Tribe

B Shleien/TSP

SP Gydesen/PNL

K Niles/TSP staff

GL Harvey/PNL

ML Blazek/TSP

M Power/TSP staff

K Niles/TSP staff

M Power, K Niles/TSP staff
CM Heeb/PNL

WA Bishop/TSP

D Powaukee/Nez Perce Tribe

JP McBride/ retired Hanford Phone worker

CM Heeb/PNL

CM Heeb/PNL

TA Ikenberry/ PNL

TA Ikenberry/ PNL

SP Gydesen/PNL

H Burgess/GE Nuclear

GL Harvey/PNL

K Niles/TSP staff

GL Harvey/PNL

GL Harvey/PNL

GL Harvey/PNL

GL Harvey/PNL

Phone

Phone

Phone

Fax

Phone

Phone

Phone

Phone

Phone
Phone Video contract

Phone Newspaper aricle

Phone Communications assessment research

Phone Communications assessment research

Phone Communicalions assessment research

Information on early iodine-131 release calculation

Use of Hanford reports in calculating early iodine-131 in April and May of 1945

Release of Native American food consumption data

Information wo be included on Nez Perce survey form

Fruit and grain palhways for data gathering, HTDS studies

Additions to Native American survey

Documents addressing radiacion dosage determination

Title listing of GE holdings that might address Hanford hisworical operations or environmental issues

Video contract 
Initiated By/

Afriliation

AH McMakin/PNL

AH McMakin/PNL

R Brich/RL
Contact

Afriliation

Type

Subject
Phone Document review plan

Fax D Shipler's comments on DOE HEDR fact sheet

F.4 


\section{Distribution}

No. of

Copies

\section{OFFSITE}

19 Technical Steering Panel

D. S. Barth

University of Nevada

4505 Maryland Parkway

Las Vegas, NV 89154

W. A. Bishop

2503 Wedgewood Court SE

Olympia, WA 98501

M. L. Blazek

Oregon Deparment of Energy

625 Marion Street N.E.

Salem, OR 97310

G. G. Caldwell

Director

Tuisa City-County Health Dept

4616 East 15 th Street

Tulsa, OK 74112

S. N. Davis

Dept. of Hydrology \& Water Resources

Bldg. 11

University of Arizona

Tucson, AZ 85721

N. J. Germond

224 Iron Mountain Blvd.

Lake Oswego, OR 97034

P. C. Klingeman

Civil Engineering Dept.

Oregon State University

Corvallis, OR 97331-2302

K. J. Kopecky

Fred Hutchinson Cancer

Research Center

1124 Columbia Street

Seattle, WA 98104
No. of

Copies

P. D. McGavran

Dept. of Health and Welfare

450 W. State Street, 4th Floor

Boise, ID 83720-5450

R. L. Morrill

Dept. of Geography

DP-10

University of Washington

Seattle, WA 98195

A. H. Murphy c/o Climate Analyses Center

National Weather Service, NOAA

W/NMC51, WWB, Room 604

Washington, DC 20233

V. Nguyen

EWA, Inc.

P. O. Box 27113

Golden Valley, MN 55427-0113

D. W. Price

Agricultural Economics

Hulbert Hall Room 211

Washington State University

Pullman, WA 99164-6210

M. A. Robkin

Radiological Sciences SB-75

University of Washington

Seattle, WA 98195

G. S. Roessler

Rt. 1, Box 139H

Elysian, MN 56028

B. Shleien

2421 Homestead Drive

Silver Springs, MD 20902

Distr.1 
A. P. Slickpoo, Sr.

P. O. Box 331

809 Nez Perce Lane

Kamiah, ID 83536

J. E. Till

Rt. 2 Box 122

Neeses, SC 29107

D. E. Walker, Jr. c/o P. Arroyo 2041 Walnut St.

Boulder, CO 80302

2 DOE Office of Scientific and Technical Information

Technical Information Center P.O. Box 62

Oak Ridge, TN 37830

M. A. Andrews

Canadian Embassy

501 Pennsylvania Ave. N.W.

Washington, DC 20001

B. Aripa

Colville Confederated Tribes

P.O. Box 150

Nespelem, WA 99155

D. M. Beck

EM-521

Trevion II

U.S. Department of Energy

Washington, DC 20585-0002

D. M. Bernick

Kirkland and Ellis

200 East Randolph Drive

Chicago, IL 60601

D. Bonga

Kalispel Tribe

P.O. Box 39

Usk, WA 99180
B. Brooks, EH-421

Department of Energy

Room J-112

Germantown, MD 20545

H. Burgess

General Electric Nuclear Energy

175 Curtner Ave.

Mail Code 822

San Jose, CA 95125

18

K. CharLee

Office of Nuclear Waste Mgmt.

Department of Ecology

99 South Sound Center

Mail Stop PV-11

Olympia, WA 98504

J. Erickson

Washington State Dept. of Health LE-13

Olympia, WA 98504-0095

D. Ernst

Spokane Tribe

P.O. Box 100

Wellpinit, WA 99040

A. Fingeret, GC-22

Department of Energy

Forrestal Bldg. Room 6H-087

1000 Independence Ave.

Washington, DC 20585

K. Gebbie, Secretary

Washington Dept of Health

MS ET-21

Olympia, WA 98504

H. A. Haerer

Golder Associates, Inc.

$1933 \mathrm{Jadwin}$ Ave., Suite 125

Richland, WA 99352 
No, of

Copies

A. P. Hull

Safety \& Environmental

Protection Division

Bldg. 535A

Brookhaven National Laboratory

Upton, NY 11973

D. B. Manders

Chronic Disease Epidemiology

Dept. of Health

MS EY-12

1408 State St.

Olympia, WA 98504

R. Mathias, S-1

Department of Energy

Forrestal Bldg. Room 7A-257

1000 Independence Ave.

Washington, DC 20585

M. McHugh

Colorado Deparment of Health

P.O. Box 7302

Crescent Branch Station

Golden, CO 80403

N. Morin

Rocky Flats Program Unit

Environmental Epidemiology Division

Colorado Dept. of Health

4210 E. 11th Ave.

Denver, CO 80220

J. D. Mulder

Public Health Liaison to EPA

U.S. EPA

1200 Sixth Ave.

Seattle, WA 98101

D. V. Nelson, ER-8.2

Department of Energy

Office of Assessment and Support

Washington, DC 20585
No. of

Copies

\author{
D. Oliver, R.S., M.P.A. \\ Hazardous Waste Coordinator \\ Toxic Substances Section \\ Dept of Social \& Health Services \\ LD-11 \\ Olympia, WA 98504 \\ M. Queahpama \\ Confederated Tribes of the \\ Warm Springs Reservation \\ P.O. Box C \\ Warm Springs, OR 97761 \\ W. J. Roberds \\ Golder Associates \\ 4104 148th N.E. \\ Redmond, WA 98052
}

J. H. Rueben

Nez Perce Tribe

P.O. Box 305

Lapwai, ID 83540

M. Sage

Centers for Disease Control 1600 Clifton Rd.

Mail Stop F-28

Atlanta, GA 30333

D. Saluskin

Confederated Tribes and Bands of the Yakima Indian Nation

P.O. Box 151

Toppenish, WA 98948

S. H. Sell, M. D.

Director, Environmental Epidemiology

Tennessee Dept. of Health \&

Environment

C-1-130 Cordell Hull Bldg.

Nashville, TN 37247-4912

Distr.3 
D. Seyler Coeur d'Alene Tribe Plummer, D 83851

G. L. Sherwood, AC-21

Department of Energy

Room D-408

Germantown, MD 20545

K. F. Sparks

Shea \& Gardner

1800 Massachusetts Ave., N.W.

Washington, D.C. 20036

J. Thomas

HEAL

1720 N. Ash

Spokane, WA 99205

B. Van Pelt

Confederated Tribes of the Umatilla Indian Reservation

P.O. Box 638

Pendleton, OR 97801

$S$. Vendetter

Benton-Franklin District Health Dept. 800 W. Canal Dr.

Kennewick, WA 99336

B. Weakley, IE-12

Department of Energy

Forrestal Bldg. Room 1E-218

1000 Independence Ave. SW

Washington, DC 20585

\section{QNSITE}

1 Hanford Environmental Health Foundation

S. E. Dietert H1-03

2 Westinghouse Hanford Company

G. D. Carpenter

D. E. Wood

B2-16

H4-51
7 DOE Field Office, Richland

T. A. Bauman, COM A7.75

R. F. Brich, TSD A5-55

J. P. Hamric, DMO A7-50

R. A. Holten, TSD A5-55

R. M. Rosselli, AMT A7-70

R. R. Tibbatts, FRD A7-88

M. W. Tieman, TSD A5-55

41 Pacific Northwest Laboratory

D. L. Alamia

D. S. Broussard

K3-70

R. A. Bumett

$\mathrm{K} 1-67$

R. Cuello

K2-05

G. H. Cunningham

P7-50

J. M. Daer

R. L. Dirkes

S. M. Finch

R. O. Gilbert

K1-59

K6-89

K6-13

K6-89

W. A. Glass

K1-85

R. H. Gray

S. P. Gydesen

G. L. Harvey

C. M. Heeb

T. A. Ikenberry

R. C. Liikala

A. H. McMakin

K $1-40$

$\mathrm{K} 1+30$

P8-55

K1-55

K6-42

K3-54

K1-57

K6-86

B. A. Napier K3-54

G. R. Petersen K1-40

J. V. Ramsdell K6-03

R. E. Rhoads K6-64

B. S. Robbins P7-64

$\begin{array}{ll}\text { D. B. Shipler } & \text { K6-89 }\end{array}$

B. K. Simanton K1-38

D. L. Stewart K6-91

W. L. Templeton K1-30

S. B. Yabusaki K6-77

Project Office Files (5) K6-89

Public Reading Room (5) A1-65

Publishing Coordination K1-11

Records Center

$\mathrm{K} 3-70$

Technical Library (2)

P8-55

Distr.4 